\title{
Sourcing nonnative mammal remains from Dos Mosquises Island, Venezuela: new multiple isotope evidence
}

\author{
Jason E. Laffoon ${ }^{1,2}$ • Till F. Sonnemann ${ }^{1,3}$ • Marlena M. Antczak ${ }^{1}$ - Andrzej Antczak ${ }^{1}$
}

Received: 10 May 2016/Accepted: 9 December 2016/Published online: 27 December 2016

(C) The Author(s) 2016. This article is published with open access at Springerlink.com

\begin{abstract}
Archeological excavations of Amerindian sites on Dos Mosquises Island, Los Roques Archipelago, Venezuela, uncovered a wide range of evidence reflecting seasonal exploitation of local resources and multiple ritual depositions of large quantities of ceramic figurines, lithics, and faunal remains. Zooarchaeological analysis revealed the presence of modified and unmodified bones and teeth from numerous imported mammal species. Local geographic and environmental conditions preclude permanent establishment of terrestrial mammal populations and as such, there are no native mammalian taxa on the island itself or the surrounding oceanic archipelago. The presence of these faunal remains on Dos Mosquises can be attributed to the intentional movement of animal resources from the mainland to Los Roques by indigenous groups in the Late Ceramic Age ( AD 1200-1500). Despite attributions to a mainland source region, little else is known about the origins of these unique specimens. Here, we apply strontium $\left({ }^{87} \mathrm{Sr} /{ }^{86} \mathrm{Sr}\right)$, oxygen $\left(\delta^{18} \mathrm{O}\right)$, and carbon $\left(\delta^{13} \mathrm{C}\right)$ isotope analyses of tooth enamel from various archeologically recovered taxa including deer, peccary, tapir, ocelot, margay, opossum, fox, and weasel to investigate their geographic origins via comparisons with macro-regional models of precipitation $\delta^{18} \mathrm{O}$ and bioavailable ${ }^{87} \mathrm{Sr} /{ }^{86} \mathrm{Sr}$. The ${ }^{87} \mathrm{Sr} /{ }^{86} \mathrm{Sr}$ results
\end{abstract}

Jason E. Laffoon

j.e.laffoon@arch.leidenuniv.nl

1 Faculty of Archaeology, Leiden University, Einsteinweg 2, 2333 CC Leiden, The Netherlands

2 Faculty of Earth and Life Sciences, Vrije Universiteit, De Boelelaan 1085, 1081 HV Amsterdam, The Netherlands

3 Institut für Archäologie Denkmalkunde und Kunstgeschichte, Otto-Friedrich-Universität Bamberg, Am Kranen 14, 96047 Bamberg, Germany are highly variable both for the overall assemblage and between specimens within the same taxa, indicating origins from different geochemical environments of mainland South America. The combined archeological and isotopic evidence are consistent with origins within the late pre-colonial Valencioid Sphere of Interaction which encompassed the Lake Valencia Basin, surrounding regions, and several offshore island groups including Los Roques archipelago.

Keywords Caribbean archeology · Strontium isotope · Oxygen isotope $\cdot$ Carbon isotope $\cdot$ Exchange $\cdot$ Provenance $\cdot$ Paleomobility $\cdot$ Mammals $\cdot$ Valencioid

\section{Introduction}

It has long been recognized that the pre-Columbian Caribbean was characterized by complex patterns of human migration, mobility, and exchange (Fewkes 1907; Lovén 1935; Rouse 1964). Highly dynamic systems of exchange operated at multiple scales ranging from local (island), to regional (archipelagic), to macro-regional (circum-Caribbean), often simultaneously (e.g., Hofman and Hoogland 2011). Multiple lines of evidence have demonstrated the migrations of people (Fitzpatrick and Ross 2010; Laffoon 2013; Rouse 1986; Siegel 1991), and the movement and/or circulation of artifacts and raw materials (Knippenberg 2007), languages (Granberry 2013), plants (Newsom and Wing 2004; Pagán-Jiménez 2013), and animals (Giovas et al. 2012; Kimura et al. 2016; Newsom and Wing 2004) into and throughout the broader Caribbean region in pre-Columbian times (see also, Curet and Hauser 2011; Hofman and Hoogland 2011; Hofman et al. 2007, 2008, 2011, 2014a, b; Keegan et al. 2013; Rodríguez Ramos 2010; Rouse 1992; Siegel 2005; and others). These processes attest to the variability of interactions 
that occurred among and between island and mainland Amerindian communities, with some evidence clearly indicating more intensive and/or durable ties between certain regions of the insular and mainland Caribbean relative to others (e.g., Boomert 2000; Hofman et al. 2011; Rouse 1992). Longdistance maritime exchange has often been most clearly evidenced by the presence of imported or exotic materials and objects in pre-Columbian archeological assemblages of the insular Caribbean with known or suspected external (mainland) origins, such as gold or guanin (an alloy of gold, silver, and copper) (Siegel and Severin 1993; Valcárcel Rojas and Martinón-Torres, 2013; Antczak et al. 2015), jade (García-Casco et al. 2013; Harlow et al. 2006), and various other semi-precious stones (Boomert 1987; Cody 1993). Thus, although it has been clearly established that these networks of exchange were prevalent throughout the prehistory of the region and included the long-distance maritime transport of a wide range of artifacts and materials, until recently, relatively little research had been conducted to more thoroughly explore their geographic origins. The limited information concerning the origins of much of Caribbean material heritage represents a notable lacuna in our knowledge of pre-colonial social articulations as provenance data have the potential to substantively contribute to reconstructions of past networks of interaction and exchange, and current debates and dialogs concerning how these relate to various other sociocultural developments in the broader region (e.g. Hofman et al. 2011, 2014a; Laffoon et al. 2014; Mol et al. 2015; Pavia et al. 2013; Rodríguez Ramos 2013).

In particular, research questions related to the topics of animal exchange and trade have been understudied in the broader region despite the documented importance of animals for both insular and mainland Amerindian groups. For example, previous zooarchaeological research in the Caribbean has demonstrated the intentional inter-island transport and introduction of hutias (a medium-sized endemic rodent) from Hispaniola (and/or Cuba) to Puerto Rico, the Bahamas, and possibly the Virgin Islands by Amerindians (Newsom and Wing 2004; Wing 2001, 2012). Furthermore, human agency has also been clearly implicated in the translocation of a wide range of mammalian species from mainland South America into the Antilles in pre-Columbian times (Newsom and Wing 2004; Stahl 2009; Wing 2001, 2008, 2012), including agouti (Newsom and Wing 2004; Wing 2001, 2012), armadillo (Giovas et al. 2012; Wing 2012), dog (Grouard 2001; Newsom and Wing 2004; Wing 2008, 2012), guinea pig (LeFebvre and deFrance 2014; Newsom and Wing 2004), opossum (Giovas et al. 2012; Grouard 2001; Newsom and Wing 2004; Wing 2012), and possibly also deer and peccary (Giovas et al. 2012; Giovas et al. 2015). Recently, there has been renewed interest in research pertaining to the presence of nonlocal (mainland) animals and animal remains in the circum-Caribbean. This pattern reflects the growing number and variety of nonnative faunal taxa are recovered from insular archeological deposits; better documented spatial-temporal distributions for various taxa; and continued development of multidisciplinary frameworks to investigate the geographic origins of faunal remains and the implications of these for disentangling regional patterns of social interaction (e.g., Antczak 1995; DeFrance 2013; Giovas 2013; Giovas et al. 2012; Haviser 1994; Laffoon et al. 2014; LeFebvre and deFrance 2014; Wing 2012).

Continued developments in isotopic analyses have contributed to an enormous expansion in the application of biomolecular approaches within archeology in general, and bioarchaeology in particular. Isotope analyses are wellestablished methods for archeological studies of human paleomobility (see reviews in Bentley 2006; Makarewicz and Sealy 2015; Montgomery 2010; Pilaar Birch 2013; Slovak and Paytan 2011), and in recent years, there has been a considerable increase in the application of similar methods to study patterns of animal exploitation, exchange, and trade in the past. Isotope zooarchaeology offers enormous potential for sourcing studies in the circum-Caribbean, owing to the geographically circumscribed nature of the island settings, the geological and environmental diversity within the insular Caribbean and between the islands and mainland, and the pronounced differences in biodiversity and species distributions between them. For example, several recent studies in the broader region have successfully used isotope analyses to explore patterns of animal trade among the ancient Maya (Thornton 2011); to document the inter-island movement of dogs within the Lesser Antilles (Laffoon et al. 2013a); and to investigate the long-distance exchange of exotic animal tooth pendants from mainland areas of Central/South America to locations on Puerto Rico (Laffoon et al. 2014).

In this study, we apply multiple isotope analyses to an assemblage of mammal dental remains (enamel) from the sites of Dos Mosquises $(n=20)$ and Domusky Norte $(n=1)$, Venezuela. The Dos Mosquises site is located on a tiny island of the same name in Los Roques archipelago (Fig. 1), an offshore oceanic atoll ca. $135 \mathrm{~km}$ north of the central coast of Venezuela in the Southern Caribbean (i.e., the chain of islands situated along the northern coast of South America from Aruba in the west to Trinidad in the east). Previous archeological investigations of Dos Mosquises and its surroundings revealed the presence of enormous shell deposits dominated by queen conch (Lobatus gigas) shells, and ritual caches containing ceramic figurines, a wide range of imported lithic tools, and the largest assemblage of exotic mammal remains $(n=93)$ ever recovered from the pre-Columbian insular Caribbean (Antczak and Antczak 2005, 2006). Based on relative and absolute dating and association with diagnostic archeological materials, particularly ceramics, the Dos Mosquises faunal remains can be attributed to Valencioid seafarers who returned to the island(s) repeatedly during the 
Fig. 1 Map showing the location of Dos Mosquises Island and Los Roques Archipelago, Venezuela. Image Source: Worldview 2Digital Globe (Google Earth, 2016a, b)

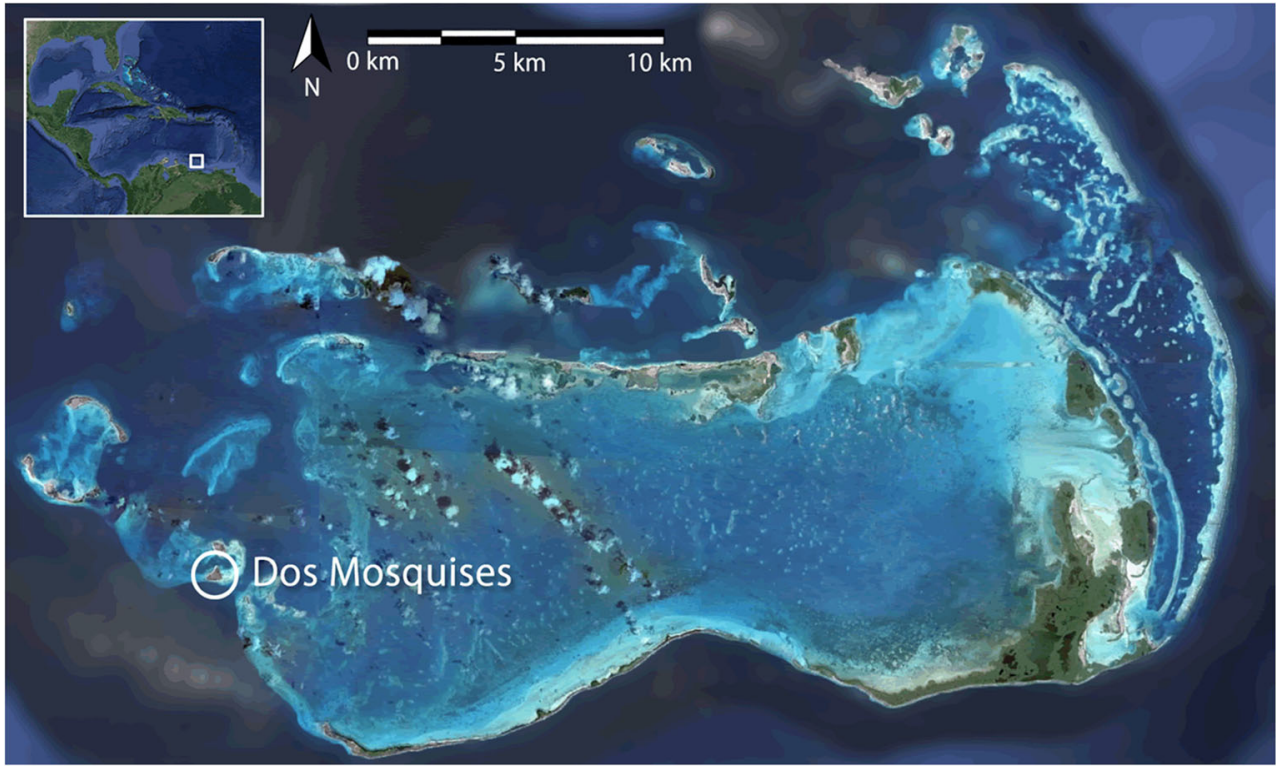

terminal phase of the Late Ceramic Age (ca. AD 1200-1500), until approximately the time of European contact (Antczak and Antczak 1999, 2017). A single deer mandible specimen derives from an Ocumaroid context on the neighboring island of Domusky Norte and slightly predates the Valencioid deposits on Dos Mosquises but was included in this study owing to the similarity in depositional context between the two sites.

Although Dos Mosquises island and the surrounding archipelago provide access to abundant marine resources, they are lacking in other essential subsistence resources. For example, terrestrial fauna and flora are exceedingly scarce, and fertile soils and reliable freshwater sources are absent altogether. These environmental conditions likely precluded permanent or year-round human habitation and indicate that preColumbian occupations were likely seasonal and focused on the extraction of specific (marine) resources (Antczak and Antczak 1999, 2006). Of particular importance for interpretations of the site's faunal assemblage is that not only the island of Dos Mosquises, but the entire Los Roques archipelago, was devoid of terrestrial mammals in pre-Columbian times (Antczak and Antczak 2006). Therefore, unlike most isotope provenance studies, the nonlocal nature of the mammalian assemblage can be established based on biogeographic principles. However, although nearly all of the mammalian specimens have been identified to the level of species, the taxonomic identifications are not highly informative of their exact mainland origins as most of them possess very extensive natural ranges within the Neotropics. Therefore, unlike similar isotopic provenance studies, the isotopic data generated for this study are not primarily used to identify which specimens are local and which are nonlocal but rather to investigate the possible geographic origins of the specimens and the associated archeological implications of the proposed origins.

\section{Isotope provenance studies}

\section{Principles of isotopic variation}

Strontium $\left({ }^{87} \mathrm{Sr} /{ }^{86} \mathrm{Sr}\right)$ isotope analyses is the most widely used isotopic method for archeological studies of human (e.g., Ericson 1985; Price et al. 1994; Sealy et al. 1995) and animal (e.g., Balasse et al. 2002; Gakuhari et al. 2013; Guiry et al. 2015; Hartman et al. 2015; Price et al. 2015; Thornton 2011), mobility, migration, and provenance studies. The principle of this method is that the strontium isotope composition of skeletal tissues is in equilibrium with that of the local biogeochemical environment, as Sr passes from rocks, via soils, into and through local food webs (Ericson 1985; Price et al. 2002).

Variation in biogenic ${ }^{87} \mathrm{Sr} /{ }^{86} \mathrm{Sr}$ ratios is primarily controlled by combined variations of inputs from the lithosphere, hydrosphere, and atmosphere (Price et al. 2002; Sillen et al. 1998). The relative proportional contributions of these different inputs can vary based on a wide range of local environmental conditions such as the presence and deposition of sea spray or marine-derived precipitation (Kennedy et al. 1998; Laffoon et al. 2012), dry fall or atmospheric dust, weathering of bedrock, and soil conditions (Bern et al. 2005; Graustein and Armstrong 1983; Pett-Ridge et al. 2009). It is the bioavailable ${ }^{87} \mathrm{Sr} /{ }^{86} \mathrm{Sr}$ as opposed to environmental or bedrock ${ }^{87} \mathrm{Sr} /{ }^{86} \mathrm{Sr}$ that is most relevant for provenance studies of biogenic tissues such as teeth and bones (Price et al. 2002; Sillen et al. 1998). Nonetheless, inputs of $\mathrm{Sr}$ from the local underlying geology are generally considered to exert the most significant control on bioavailable ${ }^{87} \mathrm{Sr} /{ }^{86} \mathrm{Sr}$ values and importantly, there is no significant fractionation of ${ }^{87} \mathrm{Sr} /{ }^{86} \mathrm{Sr}$ as it moves from the lithosphere to the biosphere (Blum et al. 2000). The ${ }^{87} \mathrm{Sr} /{ }^{86} \mathrm{Sr}$ of geological substrates is a product of the original ${ }^{87} \mathrm{Rb}$ 
abundance in the parent material and time, as ${ }^{87} \mathrm{Sr}$ is the radiogenic product of the decay of ${ }^{87} \mathrm{Rb}$ with a half-life of ca. 49 billion years (Faure and Mensing 2005). As such, younger rocks generally possess less radiogenic (lower) ${ }^{87} \mathrm{Sr} /{ }^{86} \mathrm{Sr}$ values and older rocks possess more radiogenic (higher) ${ }^{87} \mathrm{Sr} /{ }^{86} \mathrm{Sr}$. Marine carbonates can be considered an exception to this general pattern as they exhibit ${ }^{87} \mathrm{Sr} /{ }^{86} \mathrm{Sr}$ which correlate with the ${ }^{87} \mathrm{Sr} /{ }^{86} \mathrm{Sr}$ of seawater at the time of formation. In practice, nonlocal samples are defined as those whose isotopic composition falls outside of a range of estimated or measured absolute isotopic variation, which can be derived from various proxies such as local population variation, measurements of bioavailable ${ }^{87} \mathrm{Sr}{ }^{86} \mathrm{Sr}$ in local plants or animals, and predictive models of spatial ${ }^{87} \mathrm{Sr} /{ }^{86} \mathrm{Sr}$ variation (Bentley 2006).

Oxygen isotope analysis has a long history of applications to environmental and climatic research. Oxygen isotopes have been primarily utilized as temperature proxies as $\delta^{18} \mathrm{O}$ displays substantial spatial-temporal variation in precipitation and surface waters linked to climatic and geographical conditions (Dansgaard 1964). The $\delta^{18} \mathrm{O}$ of skeletal tissues reflects the $\delta^{18} \mathrm{O}$ of body water which is dominated by consumed water sources (Kohn 1996; Luz et al. 1984; Luz and Kolodny 1985) and for most animals is highly correlated with local precipitation. Oxygen isotopes in body water and thus skeletal bioapatites are enriched relative to local water in mammals in relation to internal body temperature and physiochemical processes of water flux and possibly also to interspecies variation in fraction effects as a result of variable thermophysiology (Bryant and Froelich 1995; Martin et al. 2008; Podlesak et al. 2008; Sponheimer and Lee-Thorp 1999). $\delta^{18} \mathrm{O}$ of rainfall is controlled by relative enrichment or depletion of ${ }^{18} \mathrm{O}$ (relative to ${ }^{16} \mathrm{O}$ ) via evaporation and precipitation and is thus highly conditioned by climatic and geographic variables such as latitude, altitude, temperature and amount of precipitation, and distance from coast or source of evaporated water (Dansgaard 1964; Rozanski et al.1993). In general, in more temperate climes, large intra-annual variations of rainfall $\delta^{18} \mathrm{O}$ are such that $\delta^{18} \mathrm{O}$ of incremental growing skeletal bioapatites (e.g., hypsodont enamel) are potentially informative of seasonal mobility and patterns of animal exploitation at smaller temporal scales (e.g., Balasse 2002; Pilaar Birch et al. 2016). Conversely, smaller seasonal variations in $\delta^{18} \mathrm{O}$ of rainfall in tropical climes are expected to produce less intra-annual variations in bioapatite $\delta^{18} \mathrm{O}$ and thus are potentially more directly informative of geographic origins (Laffoon et al. 2014).

Carbon isotope $\left(\delta^{13} \mathrm{C}\right)$ analyses of skeletal materials are the oldest and most well-established isotopic method for paleodietary studies in archeological research (van der Merwe and Vogel 1978; Vogel and van de Merwe 1977). The principle of this method is that the isotopic composition of diet is reflected in the isotopic composition of consumer's (biogenic) tissues. Extensive research over the last four decades has contributed greatly to elucidating the underlying sources of isotopic variation within (between different trophic levels) and between various ecosystems (DeNiro and Epstein 1978, 1981; Schoeninger et al. 1983; Schoeninger and DeNiro 1984). Continued developments in isotopic techniques, methodologies, and theories provide a solid foundation for the interpretation of stable isotope data such that they are now one of the most widely utilized tools for paleodietary assessments in archeological research (Ambrose and Krigbaum 2003; Katzenberg 2008; Lee-Thorp 2008). Variation of $\delta^{13} \mathrm{C}$ in the tissues of terrestrial mammals is ultimately conditioned by the $\delta^{13} \mathrm{C}$ of plants at the base of the food web. Plant $\delta^{13} \mathrm{C}$ is controlled by various factors but primarily by differences in photosynthetic pathways of carbon fixation (Bender 1971; Smith and Epstein 1971). The majority of plants use the $C_{3}$ pathway with average $\delta^{13} \mathrm{C}$ of $-26.5 \%$, but a small minority of plants, such as tropical grasses and sedges, use the $\mathrm{C}_{4}$ pathway with average $\delta^{13} \mathrm{C}$ of $-12.5 \%$ (Smith and Epstein 1971). As mentioned, $\delta^{13} \mathrm{C}$ analysis is predominantly used for dietary studies and less widely for mobility studies. However, owing to both the natural, and anthropogenic, distributions of $\mathrm{C}_{3}$ and $\mathrm{C}_{4}$ plants worldwide and at smaller spatial resolutions, $\delta^{13} \mathrm{C}$ isotope analyses of various human and animal tissues (teeth, bones, hair, feathers) are increasingly applied to provenance and mobility research in various fields of research ranging from wildlife ecology to forensics (e.g., Ehleringer et al. 2015; Font et al. 2015; Hobson et al. 2012; Veen et al. 2014). Additionally, owing to the existence of geographic variation in ancient foodways, $\delta^{13} \mathrm{C}$ isotope analyses are also increasingly applied to paleomobility studies in archeology, alone or more commonly in conjunction with other isotope data (e.g., Cook and Price 2015; Santana et al. 2016; Sayre et al. 2015; Schroeder et al. 2009). In this study, we use $\delta^{13} \mathrm{C}$ data as a complement to these other isotope proxies, and as indicators of inter- and intra-taxa variation in dietary niches.

\section{Isotopic variation in northern South America}

Although substantial research has been conducted on isotopic variation in Mesoamerica (e.g., Hodell et al. 2004; Price et al. 2010; White et al. 2007; Wright et al. 2010) and the insular Caribbean (Bataille et al. 2012; Laffoon 2012; Laffoon et al. 2012, Laffoon et al. 2013b), to date, relatively less is known about terrestrial isotope variation in northern South America. The lack of isotopic data from archeological skeletal materials in this region is especially notable. As such, the use of isotope data as a provenance tool is primarily reliant on subcontinental or macro-regional predictive models of bioavailable ${ }^{87} \mathrm{Sr} /{ }^{86} \mathrm{Sr}$ (Bataille et al. 2012) and precipitation $\delta^{18} \mathrm{O}$ (Terzer et al. 2013) isotope variation. Assessments of geographic origins within the broader region can also be complemented by comparison with published baseline isotope data from northcentral Venezuela (Laffoon 2012; Laffoon et al. 2012) and 
with multiple isotope results from exotic animal teeth pendants from other contexts within the circum-Caribbean (e.g., Laffoon et al. 2014; Thornton 2011). Owing to the vast size of the region spatial variation of ${ }^{87} \mathrm{Sr} /{ }^{86} \mathrm{Sr}$ and $\delta^{18} \mathrm{O}$ can only be discussed in very general terms ${ }^{87} \mathrm{Sr} /{ }^{86} \mathrm{Sr}$ variation in northern South America is highly variable. The lowest values $(<0.708)$ can be found in areas underlain by igneous bedrock (e.g., basalts and andesites) such as in isolated pockets of the northern Andes of Columbia and western Venezuela. Intermediate ${ }^{87} \mathrm{Sr} /{ }^{86} \mathrm{Sr}$ values (0.708 to 0.710 ) characteristic of continental geological settings are the most widespread and can be found throughout the vast majority of low-lying areas of northern South America. Higher ${ }^{87} \mathrm{Sr} /{ }^{86} \mathrm{Sr}$ values $(0.710$ to 0.715$)$ associated with metamorphic deposits are more rare and restricted to highland areas of the eastern and western cordilleras of the northern Andes, the Coastal Range (Cordillera de la Costa), and the Peninsula of Paria. The highest ${ }^{87} \mathrm{Sr} /{ }^{86} \mathrm{Sr}$ values $(>0.715)$ are limited to the Precambrian craton of the Guiana Shield region, occupying most of northeastern South America east of the Orinoco River.

It is important to note that relatively little is known about past (e.g., Late Holocene) $\delta^{18} \mathrm{O}$ variation, and there is essentially no $\delta^{18} \mathrm{O}$ data from archeological skeletal materials within this study region. As such, estimates of $\delta^{18} \mathrm{O}$ are by necessity based on modern precipitation $\delta^{18} \mathrm{O}$ data (from Global Network of Isotopes in Precipitation (GNIP)) from a finite number of measuring stations (IAEA) interpolated across large areas (Terzer et al. 2013). Owing to these caveats, estimates of spatial variation of $\delta^{18} \mathrm{O}$ in northern South America, and associated interpretations, must be considered tentatively and critically. Estimates of $\delta^{18} \mathrm{O}_{\text {prec }}$ presented here are based on the regionalized cluster model of Terzer et al. (2013) modified and scaled for the circum-Caribbean region (Laffoon et al. 2014). In northern South America, temporal variation of $\delta^{18} \mathrm{O}$ of precipitation $\left(\delta^{18} \mathrm{O}_{\text {prec }}\right)$ is observed both seasonally relating primarily to intra-annual differences in the temperature and amount of rainfall, while long-term variation related to climate changes (at least in the late Holocene) are, like most tropical areas, minimal compared to spatial variation of geographic variation (Lachniet and Patterson 2006, 2009). Spatial variation of $\delta^{18} \mathrm{O}_{\text {prec }}$ is primarily conditioned by altitude and distance from the coast (Dansgaard 1964; Rozanski et al. 1993). The highest $\delta^{18} \mathrm{O}_{\text {prec }}$ (greater than $-4 \%$ VSMOW) are recorded in low-lying areas of the coast, particularly the near coastal areas of far northern Columbia and northwestern Venezuela and most of northeastern Venezuela extending as much several hundred kilometers from the coast. Lower $\delta^{18} \mathrm{O}_{\text {prec }}$ values (from -4 to $-6 \%$ ) are throughout much of the lower altitude savannah and llanos of north-central and interior Venezuela and the northwestern coast of Columbia. The lowest $\delta^{18} \mathrm{O}_{\text {prec }}$ values (less than $-6 \%$ ) of the broader region are found exclusively in higher elevations in the northern Andes and Coastal ranges. Lastly, although carbon isotopes clearly display large-scale patterns of spatial variation in the northern South America (e.g., Ehleringer et al. 2000), $\delta^{13} \mathrm{C}$ of skeletal tissues are much more strongly influenced by dietary ecology in general, and the $\delta^{13} \mathrm{C}$ of food sources more particularly, such that any macro-regional assessment of $\delta^{13} \mathrm{C}$ is not particularly informative especially in relation to the large variety of taxa and associated feeding behaviors of the samples included in this study.

\section{Archeological context}

The mammal remains analyzed in this paper were recovered from the tiny Dos Mosquises Island $(350 \times 480 \mathrm{~m})$ located in the Los Roques Archipelago, an atoll-shaped coral formation with nearly 50 sandy cays situated $135 \mathrm{~km}$ north of the central Caribbean coast of Venezuela. Los Roques has no natural freshwater sources or autochthonous mammals, but avifauna and marine life is richly diversified. Systematic archeological excavations in this archipelago have been carried out since 1982, revealing 29 pre-Hispanic sites located on 21 islands and dated to AD 1000-1500 (Antczak and Antczak 2006). All the insular sites analyzed to date were interpreted as temporary campsites largely used for the exploitation of queen conch (Lobatus gigas), but also turtles, reef fishes, and probably, salt (Antczak and Antczak 2006). From approximately AD 1200 to 1500 , bearers of the Valencioid culture from the Lake Valencia Basin on the adjacent South American mainland were sending task-oriented groups to Los Roques islands to gather large quantities of queen conch, a resource that was sparsely present on the mainland's central coast (Antczak and Antczak 2005: 220). It has been calculated that between 3 and $5 \mathrm{t}$ of queen conch meat were transported annually from Los Roques to the mainland for delayed consumption and distribution (Schapira et al. 2009). Valencioid "big men" sustained this insular enterprise by building and expanding the Valencioid Sphere of Interaction in the north-central Venezuelan region (Fig. 2) which most probably lasted until the first decades of the sixteenth century (Antczak and Antczak 1999, 2016). However, the success of the insular expeditions depended not only on establishing and maintaining socio-political alliances and exacting coordination of logistics, knowledge, and technology but also depended on the beneficial assistance of the spiritual forces. The slaughter of marine animals on such a large scale was intertwined with rituals directed towards the spirits that protected the animistically oriented Valencioid voyagers. Dos Mosquises Island revealed rich deposits of pottery vessels, lithic tools, and food remains, as well as hundreds of human pottery figurines bundled together with possible shamanic "ritual kits" that included anthropomorphic and zoomorphic ceramic vessels, burners, ocarinas and pipes, bone flutes, oleoresin, mineral ochre, bodily adornments, and the mammal bones and 
Fig. 2 Map of north-central coast of Venezuela and offshore island groups, and approximate extent of Valencioid Sphere of Interaction. Image source: Landsat 7 satellite imagery (Google Earth 2016a, b)

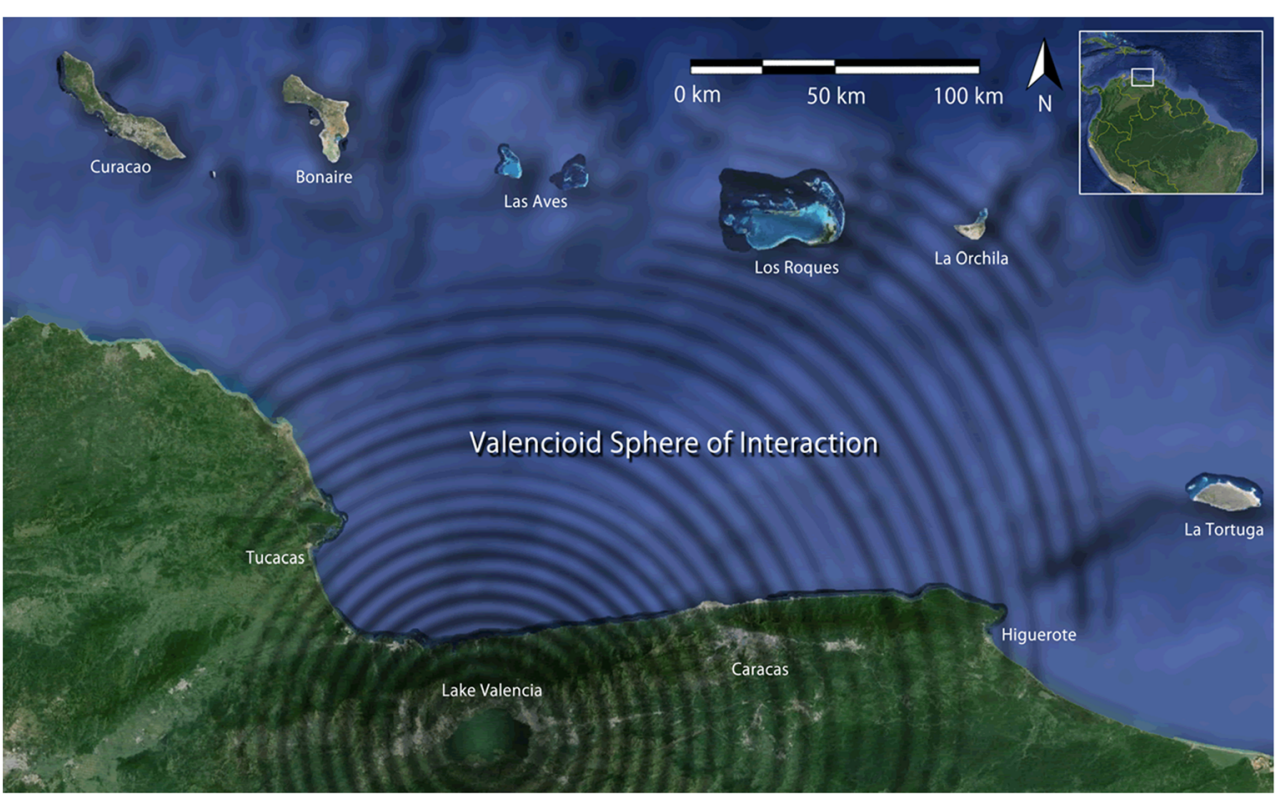

teeth discussed in this paper. It has been proposed that these corpora of shamanic paraphernalia and votive offerings had been used by adolescent and adult males who were the most frequent occupants of the insular campsites as members of the queen conch fishery task groups (Antczak and Antczak 2006).

\section{Materials and methods}

\section{Sample descriptions}

Mammal remains discussed here are part of a large assemblage of thousands of animal remains recovered in Los Roques Archipelago excavations (Antczak and Antczak 2006). Among these remains, 124 bones belong to 11 different mammal taxa; 93 of them come from the Dos Mosquises Island site and represent a minimum number of 25 individuals (Table 1). All taxa are represented by isolated elements and not by complete or even partial skeletons. Given the high quality of preservation, the intact nature of the deposits, the ritual context, the bundling of skeletal elements with various other exotic and symbolically loaded material culture, and the fact that so many of the faunal skeletal elements display evidence for modification (pendants and flutes), these remains are interpreted as likely indicating the movement of animal parts (as artifacts) as opposed to the transportation of entire animal carcasses or living animals themselves.

These remains were assigned to four techno-functional categories (Antczak 1995). Among the category worked bones and teeth are pointed bones, an awl/perforator, and flutes. Three bone flutes recovered from Dos Mosquises were made from the left radius of adult white-tailed deer (Odocoileus virginianus) and two others, found at Cayo Sal, were made out of the same skeletal element, but belonged to a brocket (Mazama sp.). Pendants in this category include three incisors of crab-eating fox (Cerdocyon thous), two canine teeth of collared peccary (Dicotyles tajacu), and one molar tooth of tapir (Tapirus terrestris). All were perforated for suspension on a string. One vertebra of brocket has ground spine tips and is also perforated for suspension. There is also another vertebra of brocket, worked in the same manner as the previous one but without perforation. The modified bone category includes 21 bones from Dos Mosquises Island including mandibles and maxilla fragments of at least 11 (MNI) individuals of small

Table 1 Identified mammal bone specimens from the Dos Mosquises site

\begin{tabular}{lll}
\hline Taxa & NISP1 & MNI2 \\
\hline Alouatta seniculus & 1 & 1 \\
Cerdocyon thous & 3 & 2 \\
Dasypus novemcinctus & 47 & $1 ?$ \\
Dicotyles tajacu & 3 & 1 \\
Didelphis marsupialis & 1 & 1 \\
Leopardus pardalis? & 3 & 3 \\
Leopardus wiedii? & 22 & 8 \\
Mazama sp. & 5 & 2 \\
Mustela frenata & 2 & 2 \\
Odocoileus gymnotis & 5 & 3 \\
Tapirus terrestris & 1 & 1 \\
Total & 93 & 25 \\
Taxa & NISP1 & MNI2 \\
\hline
\end{tabular}

Taxonomic identifications conducted by O. Linares.

${ }^{\text {a }}$ Number of identified specimens

${ }^{\mathrm{b}}$ Minimum number of individuals 
wild cats: margay (Leopardus wiedii) and ocelot (Leopardus pardalis). All the mandibles and maxillae were broken into two parts with one canine in each half. In seven mandibles, the ascending ramus was broken or cut off diagonally just behind the last teeth. Five mandibular bones display traces of cutting, chipping, or incising. One left mandible fragment shows fine traces of cutting and another right mandible has slightly broader, shallow, probably incised grooves. In both cases, the marks are situated on the buccal side at the point between the horizontal and ascending ramii and run diagonally from the superior-posterior (distal) to the inferior-anterior (mesial) side of the mandibles. The morphology, location, and orientation of the marks indicate that the cuts would have been made to facilitate the breaking-off of the ascending ramus. One specimen shows heavy traces of chipping and cutting on the upper side, which would have been done for better adjustment of the string in the process of hafting. Another fragment has traces of diagonal incisions most probably produced by the pressure of a string that tied the fresh bone to the wooden handle. Only one maxilla shows fine cutmarks on the zygomatic process. Similar marks, on human mandibular specimens, have been interpreted by White (1992: 198-9) as a result of cuts through the fibers of the masseter muscle. These marks on Dos Mosquises specimens would have been left by the stone cutting tool or molluscan shell knife when the skin and associated soft tissues were removed (skinning marks). Both types of implements produce morphologically similar cutmarks on animal bones (see Toth and Woods 1989). The unmodified bone category includes the skull of a red howler monkey (Alouatta seniculus), two cranial vaults and one complete mandibular ramus of margay cat (Leopardus wiedii), one mandibular ramus of common opossum (Didelphis marsupialis), and another two of long-tailed weasel (Mustela frenata). All these specimens pertained to the heads of the animals. Among the unmodified bones of the wild cats there are terminal phalanges of ocelot or margay cat. The category is completed by two left radii, one left tarsal of brocket (Mazama sp.) and a claw of peccary (Dicotyles tajacu). In Domusky Norte site, a mandibular ramus of brocket deer (Mazama sp.) was recovered. Finally, the category of manufacturing debris comprises splinters separated from the shafts of various mammal long bones.

Sixteen of the modified, and all of the unmodified, bones from Dos Mosquises Island were contextually associated with dozens of ceramic vessels (often decorated), human figurines, clay pipes and ocarinas, lithic microaxes, shell and stone pendants, and beads. These contexts, spatially well delimited in trenches $\mathrm{A}$ and $\mathrm{B}$, have been interpreted as central areas of the multifunctional Valencioid campsite (Antczak and Antczak 2006). The remaining five (22\%) modified bones were found scattered in the human burial area of trench $\mathrm{C}$, where small clusters that contained a few human clay figurines and decorated potsherds were recovered. Looking outside Dos
Mosquises Island for specimens for comparative analysis one unmodified mammal bone was recovered on the nearby Domusky Norte Island (note the last specimen in Table 2). Interestingly, this mandibular ramus of brocket (Mazama sp.) was recovered in a small cluster of artifacts that included human figurines, microvessels, land snail shell pendants, and resin. Even though the ceramic assemblage of Domusky Island (Ocumaroid series) is stylistically different from Dos Mosquises pottery (mainly Valencioid series), there are striking similarities in the contextual bundling of the abovementioned artifacts.

In Valencioid sites from north-central Venezuelan mainland, only a small number of mammal bones have been systematically recovered and identified. The bones of deer, fox, bear, peccary, jaguar, tapir, monkey, and dog were mentioned among others (Berry 1939; Bennett 1937; Alvarez and Casella 1983; Morales 1984; Martín 1995; Sýkora 2006). The available archeological data from Lake Valencia area confirms the special meaning attached by the bearers of the Valencioid culture to some animals and their bones (Kidder 1948: 77, Figs. 16, 2; Berry 1939: 566, 557, Pl. IV, 1; Marcano 1971[1889-1891]; von den Steinen 1904; Jahn 1927; Osgood 1943: 23; Peñalver n.d.: 14). The abundance in north-central Venezuela (the homeland of Dos Mosquises Island occupants) of the majority of mammals represented in the archeological record discussed here has been well documented from the sixteenth century to the present (Requena 1932: 233; Kidder 1948: 21; Dupouy 1946; Alvarado 1953: 247; Tello 1979; Mondolfi 1986; Eisenberg 1989; Grases 1987: 184). However, while the taxonomic identifications of insular specimens clearly indicate mainland fauna, the extensive natural ranges of these taxa (Emmons and Feer 1997; Fittkau 1969; Linares 1998) preclude accurate identifications to more specific geographic origins based on biogeography alone, necessitating the use of alternative methods (i.e., isotope analyses). In order to determine more specific locations for the island specimens, 21 individual teeth were selected from the above discussed assemblage of Dos Mosquises mammal remains and analyzed for isotope compositions. These teeth represent at least eight different mammalian taxa (Table 2, Fig. 3). The majority of the teeth have been identified to species level, while three teeth could only be identified to the genus level (e.g., Leopardus spp.).

\section{Analytical methods}

Sample preparation and measurements were conducted at the Faculty of Earth and Life Sciences, VU University Amsterdam. Details of analytical methods are reported elsewhere (Booden et al. 2008; Laffoon et al. 2013b). Briefly, the outer surface of the teeth were abraded to remove external contaminants, and the surface enamel and to expose the inner enamel, which was then extracted ( $2-5 \mathrm{mg}$ ) using a hand-held 
Table 2 Sampling information and isotope results for Dos Mosquises mammalian teeth

\begin{tabular}{|c|c|c|c|c|c|c|}
\hline Sample no. & Common name & Taxa & Element & ${ }^{87} \mathrm{Sr} /{ }^{86} \mathrm{Sr}$ & $\delta^{13} \mathrm{C} \%$ & $\delta^{18} \mathrm{O} \%$ \\
\hline $9060^{\mathrm{a}}$ & Collared Peccary & Pecari tajacu & Canine & 0.71135 & -11.9 & -4.3 \\
\hline $16770^{\mathrm{a}}$ & Brazilian Tapir & Tapirus terrestris & Molar & 0.70965 & -13.8 & -3.2 \\
\hline $9064^{\mathrm{a}}$ & Common Fox & Cerdocyon thous & Incisor & 0.71119 & -9.2 & -3.7 \\
\hline VEN6 ${ }^{\mathrm{a}}$ & Common Fox & Cerdocyon thous & Incisor & 0.71149 & -9.2 & -3.4 \\
\hline 582 & Ocelot & Leopardus pardalis & Molar & 0.71071 & -9.0 & -4.7 \\
\hline 16,781 & Ocelot & Leopardus pardalis & Premolar & 0.71255 & -6.9 & -3.6 \\
\hline 1599 & Margay & Leopardus wiedii & Premolar & 0.71245 & -6.0 & -3.1 \\
\hline 583 & Margay & Leopardus wiedii & Premolar & 0.71317 & -8.1 & -4.2 \\
\hline 609 & Margay & Leopardus wiedii & Premolar & 0.71104 & -4.8 & -2.3 \\
\hline 613 & Margay & Leopardus wiedii & Premolar & 0.70971 & -7.8 & -5.5 \\
\hline 621 & Margay & Leopardus wiedii & Premolar & 0.71436 & -6.2 & -3.2 \\
\hline 1132 & Margay & Leopardus wiedii & Premolar & 0.71132 & -7.0 & -4.3 \\
\hline 1154 & Margay & Leopardus wiedii & Premolar & 0.7099 & -7.8 & -4.7 \\
\hline 16779 & Margay & Leopardus wiedii & Premolar & 0.71052 & -6.2 & -4.6 \\
\hline 4502 & felid & Leopardus sp. & Molar & 0.70958 & -10.0 & -4.0 \\
\hline 4504 & felid & Leopardus sp. & Canine & 0.70985 & -7.9 & -4.7 \\
\hline 4505 & felid & Leopardus sp. & Molar & 0.70982 & -8.8 & -4.9 \\
\hline 1135 & Common Opossum & Didelphis marsupialis & Incisor & 0.71032 & -7.3 & -5.0 \\
\hline 4506 & Long-tailed Weasel & Mustela frenata & Canine & 0.7101 & -7.7 & -4.4 \\
\hline 4507 & Long-tailed Weasel & Mustela frenata & Canine & 0.71079 & -8.2 & -5.1 \\
\hline $4387^{\mathrm{b}}$ & Brocket Deer & Mazama sp. & Molar & 0.71131 & -8.6 & -4.5 \\
\hline
\end{tabular}

${ }^{a}$ Perforated tooth root, likely for suspension as adornment

${ }^{\mathrm{b}}$ Specimen recovered from Ocumaroid contexts from the neighboring island of Domusky Norte

drill and a pre-cleaned, diamond-tipped drill bit. Homogenized enamel (powder) samples were then sequentially treated with $2.5 \%$ bleach $(\mathrm{NaOCl})$ and $0.1 \mathrm{~N}$ acetic acid $\left(\mathrm{CH}_{3} \mathrm{COOH}\right)$; rinsed to neutral $\mathrm{pH}$ with demineralized, deionized $\mathrm{H}_{2} \mathrm{O}$ (Milli-Q); dried down; and then dissolved in $3 \mathrm{~N}$ nitric acid $\left(\mathrm{HNO}_{3}\right)$. Strontium separation via ion chromatography was accomplished by loading nitrated samples onto ultra-clean cation exchange columns loaded with $\mathrm{Sr}$-specific crown ether resin (Sr-Spec, Eichrom Inc.). Purified Sr samples were loaded onto degassed rhenium filaments, and $\mathrm{Sr}$ isotope compositions were measured on a ThermoFinnigan MAT 262 RPQ Plus, thermal ionization mass spectrometer (TIMS). Repeat measurements of the NBS-987 international standard yielded mean ${ }^{87} \mathrm{Sr} /{ }^{86} \mathrm{Sr}=0.71025 \pm 0.00002(1 \sigma)$. Typical analytical uncertainty is $<0.00001$ and total procedural blanks are $<100 \mathrm{pg}$. The measured values were normalized by applying a correction equal to the difference between the measured ${ }^{87} \mathrm{Sr}{ }^{86} \mathrm{Sr}$ value of the NBS-987 standard and the generally accepted value of 0.710240 . Oxygen and carbon isotopes were simultaneously measured on a Finnigan DeltaPlus, isotope ratio mass spectrometer (IRMS), following reaction of the powdered enamel sample $(\sim 0.7 \mathrm{mg})$ with $100 \%$ orthophosphoric acid $\left(\mathrm{H}_{3} \mathrm{PO}_{4}\right)$ and sequestration of the released carbon dioxide $\left(\mathrm{CO}_{2}\right)$ with a Gasbench II universal automated interface. Long-term reproducibility of the NBS-19 international standard is $<0.2 \%$ of both $\delta^{13} \mathrm{C}$ and $\delta^{18} \mathrm{O}$. Stable isotope values are reported in the delta $(\delta)$ notation, in parts per thousand (\%o) relative to Vienna Pee Dee Belemnite (VPDB).

\section{Results and discussion}

Relevant sampling information and isotope results are presented in Table 2 (and displayed in Figs. 4, 5, and 6). The $\delta^{18} \mathrm{O}$ values (Fig. 5) display a fairly limited range of variation (range -5.5 to $-2.3 \%$ ). This pattern is not overly surprising given that there is relatively limited variation in precipitation $\delta^{18} \mathrm{O}$ in the study region (Fig. 6). Furthermore, there are multiple sources of variation that could influence the patterning of enamel $\delta^{18} \mathrm{O}$ within this sample set including inter-species differences in fractionation of between consumed water and bioapatite for mammals in general (Martin et al. 2008) and felines in particular (Pietsch et al. 2011). Owing to these concerns, and the additional potential complications of long-term changes in precipitation $\delta^{18} \mathrm{O}$ within the study area, we consider the $\delta^{18} \mathrm{O}$ data to be less informative of origins and we place much more interpretive weight on the ${ }^{87} \mathrm{Sr} /{ }^{86} \mathrm{Sr}$ data. Nevertheless, although the generated $\delta^{18} \mathrm{O}$ data are not 


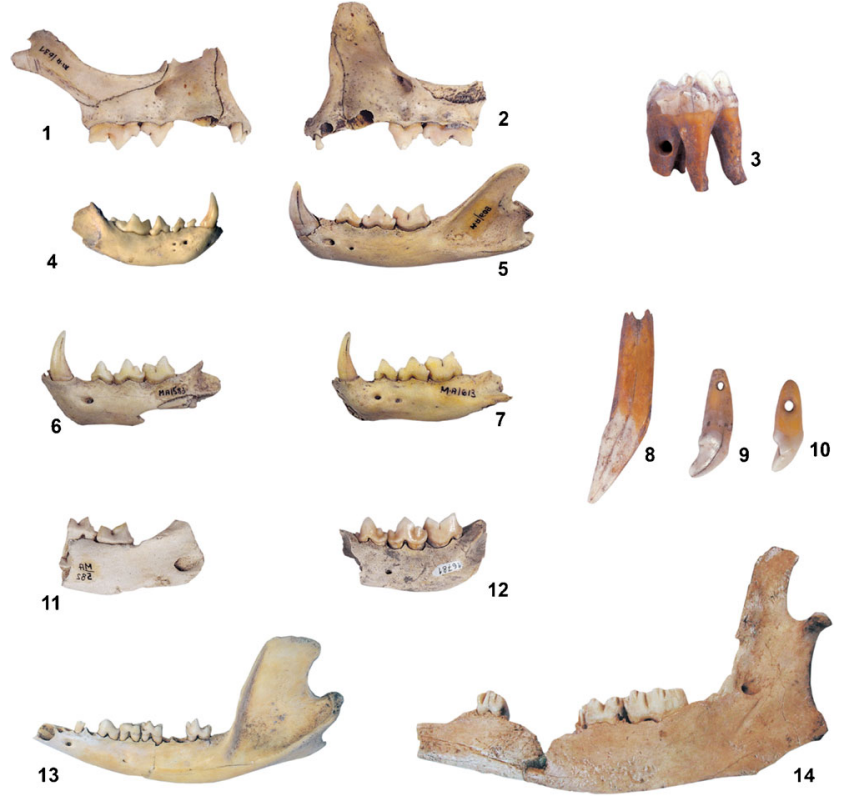

Fig. 3 Selection of mammalian dental remains from Dos Mosquises Island of which some teeth were analyzed for this study (see Table 2): 1, 2, maxillae Leopardus wiedii (nos. 631 and 640); 3, molar Tapirus terrestris (no. 16770); 4, mandible Mustela frenata (no. 4507); 5-7, mandibles Leopardus wiedii (nos. 609, 583, and 613); 8, canine Tayassu tajacu (no. 9060); 9, 10, incisors Cerdocyon thous (nos. 9064 and VEN6); 11, 12, mandibles Leopardus pardalis (nos. 582 and 16781); 13, mandible Didelphis marsupialis (no. 1135); and 14, mandible Mazama sp. (no. 4387)

particularly informative of geographic origins in this particular dataset, we report them here in the hopes that further advancements in understandings of oxygen isotope fractionation processes and the spatial distribution of water and bioapatite $\delta^{18} \mathrm{O}$ in the study region will lead to more nuanced assessments of origins in the future.

It is important to note that all samples possessed ${ }^{87} \mathrm{Sr} /{ }^{86} \mathrm{Sr}$ that are much higher than those typically recorded for bioavailable samples in the insular Caribbean which rarely exceed 0.7095 and are entirely consistent with mainland origins on South America. Furthermore, although no local bioavailable samples from Dos Mosquises were analyzed for $\mathrm{Sr}$ isotope composition, based on the underlying bedrock geology of marine carbonates, and any contributions from the seaspray or marine-derived precipitation, the local biosphere signal should be $\sim 0.7092$. As all of the analyzed specimens possess much higher values, we consider this indirect evidence for the biogenic source for the measured $\mathrm{Sr}$ values. Similar to the $\delta^{13} \mathrm{C}$ results and in contrast to the $\delta^{18} \mathrm{O}$ results, the ${ }^{87} \mathrm{Sr} /{ }^{86} \mathrm{Sr}$ data display a high degree of variance (range 0.7096 to 0.7144$)$.

Closer inspection of the ${ }^{87} \mathrm{Sr} /{ }^{86} \mathrm{Sr}$ data (Fig. 7) reveals several interesting patterns. First, none of the analyzed samples possess ${ }^{87} \mathrm{Sr} /{ }^{86} \mathrm{Sr}$ less than 0.7095 or greater than 0.7145 . As the $\mathrm{Sr}$ isotope method of provenance primarily relies on exclusionary principles, this result permits us to discount many

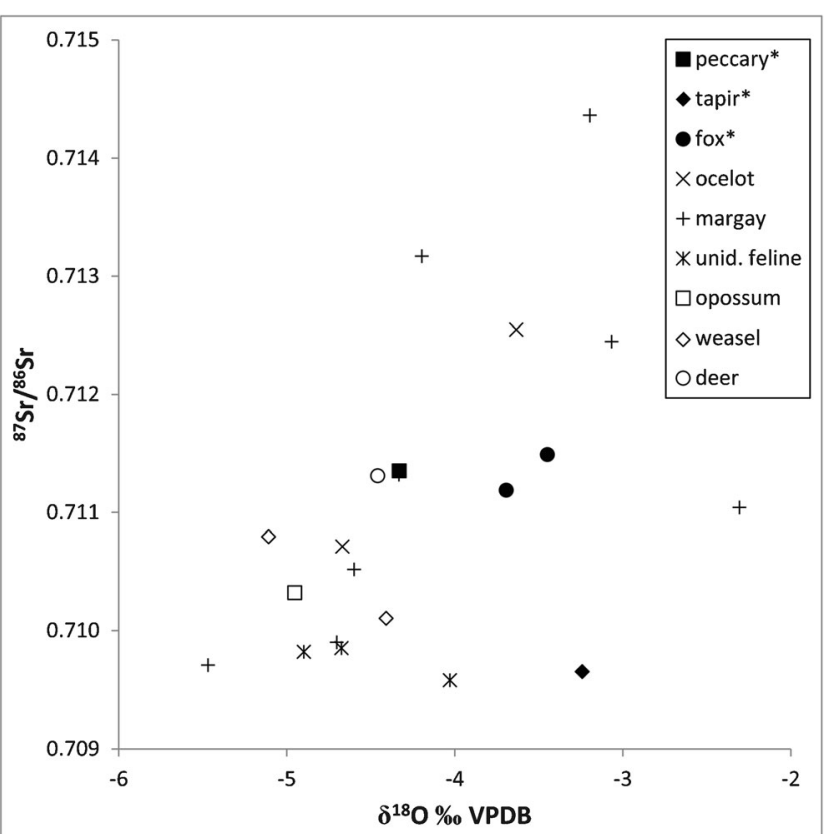

Fig. 4 Bivariate plot of ${ }^{87} \mathrm{Sr} /{ }^{86} \mathrm{Sr}$ and $\delta^{18} \mathrm{O}$ values of Dos Mosquises samples plotted by taxa. Asterisk indicates that element is perforatedpendant

regions of the surrounding mainland as possible origins (Fig. 8). More specifically, much of the Isthmo-Columbian region, spanning northwestern Columbia into southern Central America, is underlain primarily by igneous lithologies possessing ${ }^{87} \mathrm{Sr} /{ }^{86} \mathrm{Sr}<0.708$ and can be excluded as possible origins. Additionally, many of the valleys of Columbia and extensive low-lying areas of northwestern and north-central Venezuela contain sedimentary lithologies with large areas having predicted bioavailable $<0.7095$ and can also be excluded. Lastly, most of the Guiana Shield region (southeast of the Orinoco River) is underlain by a Precambrian craton possessing very elevated ${ }^{87} \mathrm{Sr} /{ }^{86} \mathrm{Sr}(>0.715)$ and can also be eliminated as possible source regions. The vast majority of the analyzed samples $(n=17)$ possess ${ }^{87} \mathrm{Sr} /{ }^{86} \mathrm{Sr}$ values between 0.7095 and 0.7115. Although much of northern South America remains poorly characterized in terms of bioavailable ${ }^{87} \mathrm{Sr} /{ }^{86} \mathrm{Sr}$, these values fall generally within the range of bioavailable ${ }^{87} \mathrm{Sr} /{ }^{86} \mathrm{Sr}$ for northern coastal Venezuela (Laffoon et al. 2012). Four feline samples (three margays and one ocelot) have ${ }^{87} \mathrm{Sr} /{ }^{86} \mathrm{Sr}$ values falling between 0.712 and 0.715 . Such moderately elevated values correspond to areas underlain by metamorphic bedrock and can be found in fairly large swaths of the northern Andes of Columbia and Venezuela including the central component of the Cordillera Occidental (southeast of Lake Maracaibo), along the northern boundary of the Guiana Shield (on the right bank of the Lower Orinoco), and in much smaller isolated pockets in the Caribbean Andes surrounding the Lake Valencia Basin, particularly in the Serranía del Interior, the more southerly range that runs 
Fig. 5 Precipitation $\delta^{18} \mathrm{O}$ isoscape of the circum-Caribbean region with inset of north-central South America. Map modified from Fig. 3 in Laffoon et al. (2014: 225) based on the RCWIP model of Terzer et al. (2013) and the data files available from IAEA Web site (www.iaea.org/water)

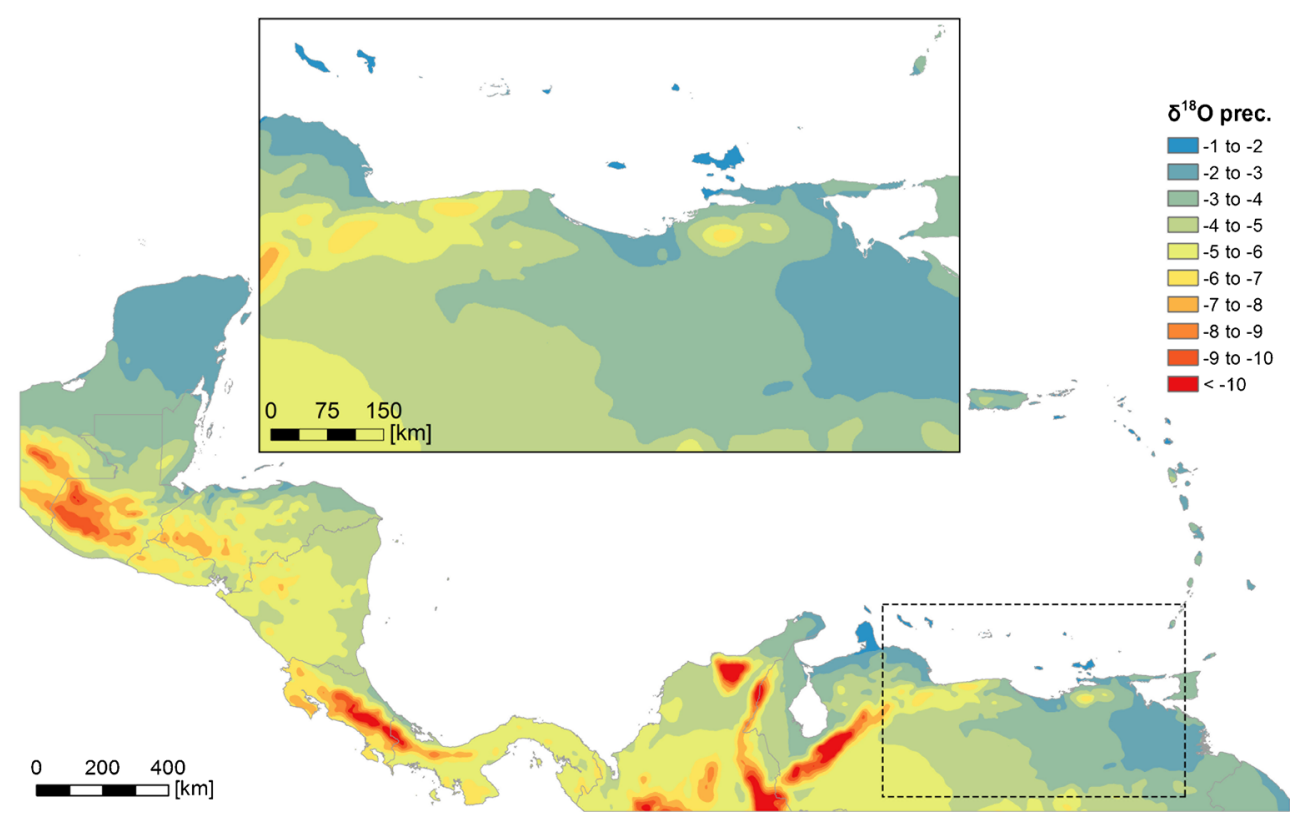

parallel to and inland of the Cordillera de la Costa of northern Venezuela.

The carbon isotope results do not directly inform upon questions concerning geographic origins but can complement interpretations of the oxygen and strontium isotope results. The $\delta^{13} \mathrm{C}$ results contribute fundamental baseline data concerning the dietary ecology of the various analyzed taxa, which is particularly important considering the overall lack of baseline faunal stable isotope data for this macro-region. The $\delta^{13} \mathrm{C}$ values display a very broad range of values (Fig. 4), as expected based on the wide variety of sampled taxa and their diverse dietary behaviors. For example, the tapir and peccary samples have the two most depleted values in the dataset, indicating predominant consumption of $\mathrm{C}_{3}$ plants. The single deer specimen has an intermediate, moderately enriched $\delta^{13} \mathrm{C}$ value indicating considerable contributions from both $\mathrm{C}_{3}$ and $\mathrm{C}_{4}$ resources. The opossum is the most likely omnivorous mammal in the sample set, and it too possesses an intermediate $\delta^{13} \mathrm{C}$ value. All of the other samples are best described as

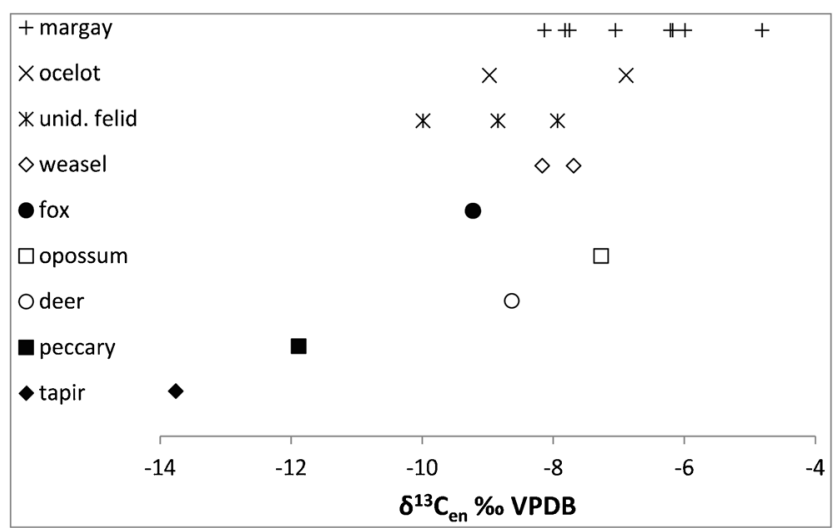

Fig. 6 Enamel $\delta^{13} \mathrm{C}$ values of Dos Mosquises samples plotted by taxa carnivorous, and these display higher (enriched in ${ }^{13} \mathrm{C}$ ) and more variable $\delta^{13} \mathrm{C}$ values ranging from $-10.0 \%$ o for one of the unidentified felids to as high as $-4.8 \%$ o for one of the margay samples. The generally higher $\delta^{13} \mathrm{C}$ values of the carnivorous taxa results from trophic level enrichment effects; the direct consumption of $\mathrm{C}_{4}$ terrestrial animal protein (i.e., herbivores or omnivores that consume $\mathrm{C}_{4}$ plants), the consumption of aquatic protein resources, or a combination of these factors. Their high variation in $\delta^{13} \mathrm{C}$ values reflects dietary differences likely related to variations in local habitats, resource availability, and the adaptability of these carnivorous taxa in terms of prey selection.

Having presented the results of the three isotope systems separately, we now asses them jointly. Assessment of the bivariate plot of ${ }^{87} \mathrm{Sr} /{ }^{86} \mathrm{Sr}$ and $\delta^{18} \mathrm{O}$ (Fig. 5) reveals that several samples have nearly identical values for both ${ }^{87} \mathrm{Sr} /{ }^{86} \mathrm{Sr}$ and $\delta^{18} \mathrm{O}$. One example is a cluster including the peccary, the deer,

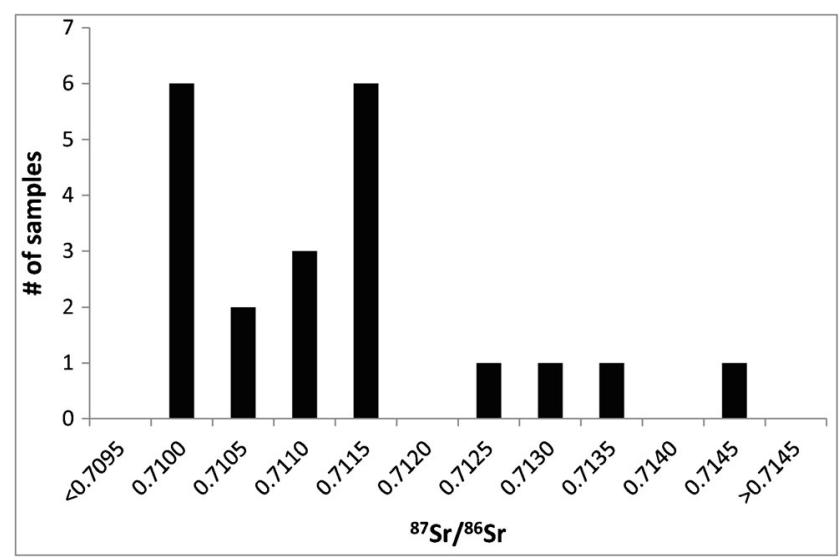

Fig. 7 Histogram of ${ }^{87} \mathrm{Sr} /{ }^{86} \mathrm{Sr}$ values from Dos Mosquises mammalian tooth samples 
Fig. 8 Bioavailable ${ }^{87} \mathrm{Sr} /{ }^{86} \mathrm{Sr}$ isoscape of the circum-Caribbean region with inset of north-central South America. Map adapted from Fig. 2 in Laffoon et al. (2014: 225) based on original from Bataille et al. (2012)

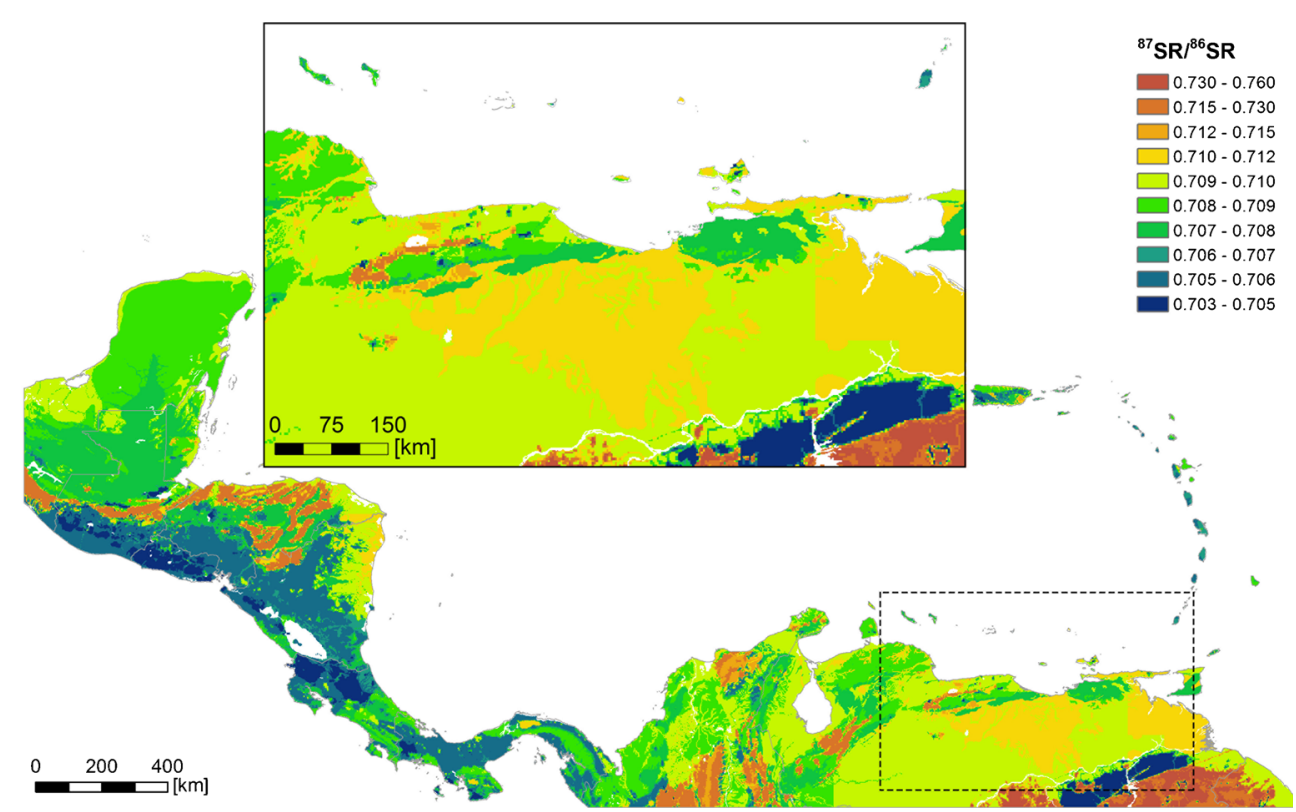

and one of the margay samples $\left({ }^{87} \mathrm{Sr} /{ }^{86} \mathrm{Sr}, 0.7113 ; \delta^{18} \mathrm{O}\right.$, $-4.3 \%$ ). Other examples include a cluster of two unidentified felids and a margay $\left({ }^{87} \mathrm{Sr} /{ }^{86} \mathrm{Sr}, 0.7099 ; \delta^{18} \mathrm{O},-4.8 \%\right.$ ) and both of the fox samples $\left({ }^{87} \mathrm{Sr} /{ }^{86} \mathrm{Sr}, 0.711 ; \delta^{18} \mathrm{O},-3.6 \%\right.$ ). These last two clusters importantly consist of samples that are analytically identical (within error) in terms of their $\delta^{13} \mathrm{C}$ values. Equivalent values for a particular isotope system does not confirm shared origins; however, if two (or more) samples found in the same or highly similar depositional contexts have nearly identical values for three separate (independent) isotope proxies, then shared or at least similar geographic origins can be considered plausible, if not probable. Such interpretations are probably better supported for those samples which cluster isotopically and are of the same taxa, as these are not reliant on potentially problematic inter-species comparisons of $\delta^{18}$ O. Possible complications introduced by temporal variations in precipitation $\delta^{18} \mathrm{O}$ are likely reduced in our data set owing to the relatively tight chronological clustering of the samples (less than three centuries).

Besides the aforementioned data clusters, which cross-cut taxonomic identifications, there appears to be little if any patterning to the isotopic data relative to taxonomy. One notable pattern is that the felid isotope data in general and the margay samples in particular display a higher degree of variation than the rest of the dataset for all three isotopic proxies. This pattern could be an artifact of sample sizes, or alternatively may reflect more diverse origins for these specimens. One possibility is that such a pattern could be correlated with the natural distribution of the animals themselves, in terms of home range sizes and habitat preferences. The mammal taxa included herein have extremely variable home ranges, with the largersized ones, such as the peccary and tapir, having home ranges sometimes in excess of $100 \mathrm{~km}^{2}$, while on the other end of the spectrum, margays typically have much smaller home ranges from 10 to $15 \mathrm{~km}^{2}$ (Tewes and Schmidly 1987). As such, and considering that Neotropical cats are generally solitary and territorial creatures, it might be expected that the collection/ hunting of multiple individuals would require that they be obtained from different areas and thus possibly would possess different isotope values. The high variation in $\delta^{13} \mathrm{C}$ values among the Neotropical feline samples, and margays specifically, lends some independent support to this notion assuming that individuals of these species deriving from different locales may adapt their feeding behaviors to local ecological conditions.

Based on comparative assessment of the isotopic evidence and information derived from the archeological context, we can tentatively propose a few possible scenarios. One possible scenario, given the very widespread natural distribution of these animals, is that despite being ultimately deposited on Dos Mosquises by Valencioid task groups, they may have been ultimately obtained via long-distance exchange from outside of the Valencioid Sphere of Interaction. This scenario is considered quite plausible, in light of the widespread circulation of social valuables by Amerindians of the lowland tropics (Boomert 2000), and recent isotopic evidence documenting the long distance movement $(>1000 \mathrm{~km})$ of pendants manufactured from the teeth of mainland mammals to the insular Caribbean (Laffoon et al. 2014). In such a scenario, it would not be possible to specify the origins of these specimens beyond what has already been discussed. Conversely, given the ubiquitous presence of Valencioid cultural materials at the site, particularly ceramic figurines with clear affinities to the Lake Valencia region, in direct association with the recovered mammalian skeletal remains, it is reasonable to assume that the animals also originated within the Valencioid Sphere 
of Interaction. Based on these premises, it is noteworthy that despite the fact that the isotope results indicate diverse origins at local scales, the isotopic evidence for all of the analyzed specimens is consistent with origins in and around the Lake Valencia drainage (Figs. 7 and 8). For example, within the Valencioid Sphere of Interaction, the samples with ${ }^{87} \mathrm{Sr} /{ }^{86} \mathrm{Sr}$ values ranging from 0.7095 to 0.7115 are consistent with origins in widespread areas underlain by continental-derived sedimentary deposits, both within and surrounding the Lake Valencia basin and along much of the Cordillera de la Costa. The four samples with the highest ${ }^{87} \mathrm{Sr} /{ }^{86} \mathrm{Sr}$ values ranging from 0.7115 to 0.7145 (three margay and one unidentified felid) are consistent with origins underlain by more heavily deformed metamorphic rocks, such as those found in much of the Serranía del Interior and a smaller portion of the Cordillera de la Costa between Lake Valencia proper and Caracas.

Turning lastly to the archeological implications of these results, a few tentative suggestions can be proposed. Although it can be safely assumed that all of the individual animals were hunted, it is unlikely that the main purpose of hunting some of them (especially the carnivores) was for subsistence (i.e., to consume their flesh). It seems more likely that some of the animals, such as the margay and ocelot, and possibly even the fox, were hunted for other reasons, for example for their fur or to make use of their teeth and bones as raw materials. Even for the larger herbivorous mammals such as the tapir and peccary, which were likely hunted for their meat, the use of their teeth indicates that these animals' remains served multiple functions. This point taken together with the rather conspicuous display of some of the teeth pendants as items of personal adornment may suggest that much of the mammalian faunal assemblage may represent "hunting trophies" (Antczak 1995). As a corollary, the presence of these objects in highly ritualized contexts together with iconic Valencioid ceramic figurines could also be interpreted as materialized claims of access to Dos Mosquises (or the Los Roques archipelago more broadly) and the rich marine resources available for exploitation there (Antczak and Antczak 2006).

\section{Conclusions}

Analyses of isotopic compositions $\left({ }^{87} \mathrm{Sr} /{ }^{86} \mathrm{Sr} ; \delta^{18} \mathrm{O}\right.$ and $\left.\delta^{13} \mathrm{C}\right)$ were conducted on an assemblage of exotic mammal teeth recovered from ritual deposits at the pre-colonial site of Dos Mosquises, Los Roques Archipelago, Venezuela. Atypical of most isotope provenance studies, the nonlocal nature of the specimens was known a priori as these islands are and were entirely devoid of terrestrial mammalian fauna. As such, research questions focused on investigating the origins of these artifacts on the South American mainland. The isotope results displayed a high degree of variation in $\delta^{13} \mathrm{C}$ and ${ }^{87} \mathrm{Sr} /{ }^{86} \mathrm{Sr}$, but more homogenous $\delta^{18} \mathrm{O}$. The variation in $\delta^{13} \mathrm{C}$ between certain taxa is interpreted as reflecting broad-scale dietary differentiation between $\mathrm{C}_{3}$ and $\mathrm{C}_{4}$ herbivores, omnivores, and carnivores. Variation in $\delta^{13} \mathrm{C}$ within certain taxa (e.g., margay) is interpreted as reflecting different diets and possibly also differences in local ecological settings and habitats. The highly variable ${ }^{87} \mathrm{Sr} /{ }^{86} \mathrm{Sr}$ results rule out the possibility of shared origins for all specimens and indicate rather diverse geographic origins for the overall assemblage. Several sets of samples (including different taxa) shared highly similar isotope values for two or three independent isotope proxies and thus could have originated from the same locations. The felids in general and the margay in particular displayed highly variable values for all three isotope proxies, indicating generally diverse origins. To what extent this latter patterning reflects natural distribution patterns of these species, or choices made by Amerindian hunters, or systems of regional exchange cannot be determined at this time.

Comparative assessment of the isotope results with the spatial patterning of bioavailable ${ }^{87} \mathrm{Sr} /{ }^{86} \mathrm{Sr}$ in northern South America based on empirical and predictive models enabled many regions to be excluded as possible origins. The Lake Valencia Basin and surroundings (corresponding to the Central Cordillera Bioregion) taken together are the geographically most proximate region which possesses the necessary geochemical variation to account for the isotopic diversity of all of the analyzed exotic tooth specimens. Based on the totality of the evidence (both isotopic and archeological), we tentatively propose that all samples could have originated within the spatial extent of the Valencioid Sphere of Interaction which linked various Amerindian communities within the Lake Valencia and surrounding regions during the Late Ceramic Age. If this predicted "region" of origin is accurate, then this would indicate the movement of most of these specimens within $\sim 200-300 \mathrm{~km}$ from their proposed places of origin on the mainland to the islands of Los Roques. Alternatively, if the samples with the four highest ${ }^{87} \mathrm{Sr} /{ }^{86} \mathrm{Sr}$ values (all felids) do not originate from within the Valencioid Sphere of Interaction, then the next closest regions that are consistent with such ${ }^{87} \mathrm{Sr} /{ }^{86} \mathrm{Sr}$ values are much farther away $(>500 \mathrm{~km})$. In either case, these results represent another well-documented example of long-distance movement of animal remains and social valuables more generally by Amerindian groups of the circum-Caribbean region. Assessing these results within a broader context, it is clear that different regions of the insular and mainland Caribbean became engaged in very different forms of interaction and articulation at various times throughout the pre-colonial era. The isotope results from this study are consistent with the direct transport and deposition of materials from a fairly restricted region of north-central South America by nonresident groups, likely focused on seasonal resource extraction activities starting in the Late Ceramic Age ( AD 600-1500). This 
contrasts with the results of previous similar isotope provenance studies of mammal remains in the Caribbean region, which indicate that permanent resident populations in places such as Puerto Rico and Vieques, in the northeastern Caribbean, were engaged in much longer distance exchange networks extending from the Isthmo-Columbian region to the Guiana Shield region thousands of kilometers away during the Early Ceramic Age (Laffoon et al. 2014). Nonetheless, some questions concerning these topics deserve further consideration, including the timing of the collection of these artifacts and the exact mechanism of their movement (direct acquisition or exchange).

Current and future research avenues including the further development of isoscapes of bioavailable ${ }^{87} \mathrm{Sr} /{ }^{86} \mathrm{Sr}$ and $\delta^{18} \mathrm{O}$ for South and Central America at multiple scales (local, regional, macro-regional) can contribute to refined estimations of geographic origins. The application of other types of isotope analyses, including sulfur $(\mathrm{S})$, lead $(\mathrm{Pb})$, and neodymium $(\mathrm{Nd})$, also has the potential to shed further light on the provenance of these and similar artifacts and are the focus of ongoing research. Additionally, none of the mammalian bone materials from Dos Mosquises, including rare specimens of howler monkey (Alouatta seniculus) crania and deer (Mazama sp.; Odocoileus virginianus) bone flutes that are unique in the insular Caribbean, have yet been isotopically analyzed for provenance purposes in part because of concerns with the susceptibility of bone ${ }^{87} \mathrm{Sr} /{ }^{86} \mathrm{Sr}$ to post-mortem alteration. However, owing to the exceptional state of preservations of the bone materials, it may be worthwhile to pursue this line of research as well. Analyses of patterns of microwear on these skeletal remains may reveal more about the artifact biographies in relation to production and use (or lack thereof). Such evidence may also further shed light on certain aspects of the artifact life histories that are missing, i.e., between the endpoints of the location(s) of origin of the raw materials (on the mainland) to their locations of deposition (on Dos Mosquises). Placing these artifacts within a larger comparative framework assessing the production, use, movement, and meaning of other components of the archeological assemblages of Dos Mosquises and the Valencioid Sphere of Interaction more generally is the focus of ongoing research.

Acknowledgements The research leading to these results has received funding from the Netherlands Organization for Scientific Research (NWO grant no. 360-62-060) "Island Networks: modelling intercommunity social relationships in the Lesser Antilles across the historical divide (AD 1000-1800)" research program in collaboration with the European Research Council under the European Union's Seventh Framework Programme (FP7/2007-2013)/ERC grant agreement no. 319209 in the context of the "Nexus1492: New World Encounters in a Globalizing World" research program, supervised by Corinne Hofman. We kindly thank Omar Linares for the initial identification of the mammalian skeletal materials from the Dos Mosquises site, and Włodzimierz Jedrzejewski for his insightful comments on an earlier version of this paper. The authors also gratefully acknowledge Hubert Vonhof and
Gareth Davies at the Faculty of Earth and Life Sciences, VU University Amsterdam, for their contributions to the isotope analyses. This paper was greatly improved by the insightful comments of two anonymous reviewers.

Open Access This article is distributed under the terms of the Creative Commons Attribution 4.0 International License (http:// creativecommons.org/licenses/by/4.0/), which permits unrestricted use, distribution, and reproduction in any medium, provided you give appropriate credit to the original author(s) and the source, provide a link to the Creative Commons license, and indicate if changes were made.

\section{References}

Alvarado L (1953) Glosario de Voces Indígenas de Venezuela, Vol. I. Ministerio de Educación, Caracas

Alvarez I, Casella J (1983) Modo de Vida y Ambiente. Unpublished Tesis de Grado, Escuela de Sociología y Antropología. Universidad Central de Venezuela, Caracas

Antczak A (1995) Mammal bone remains from the late prehistoric Amerindian sites on Los Roques archipelago, Venezuela: an interpretation. In: Proceedings of the XVIth international congress for Caribbean archaeology. Conseil Régional de la Guadeloupe, Basse Terre, pp. 83-99

Antczak A, Antczak MM (1999) La Esfera de Interacción Valencioide. In: Arroyo M, Blanco L, Wagner E (eds) El Arte Prehispánico de Venezuela. Fundación Galería de Arte Nacional, Caracas, pp. 136-154

Antczak A, Antczak MM (2005) Pre-Hispanic fishery of the queen conch, Strombus gigas, on the islands off the coast of Venezuela. In: Miloslavich P, Klein E (eds) Caribbean marine biodiversity: the known and the unknown. DEStech Publications Inc., Lancaster, pp. 213-243

Antczak A, Antczak MM (2017) Caribbean pottery figurines. In: Insoll T (ed) The Oxford handbook of prehistoric figurines. Oxford University Press, Oxford (in press)

Antczak MM, Antczak A (2006) Los Ídolos de las Islas Prometidas: Arqueología Prehispánica del archipelago de Los Roques. Editorial Equinoccio, Caracas

Antczak A, Antczak MM, Valcárcel Rojas R, Sýkora A (2015) Rethinking Guanín: the role of northern Venezuela in the circulation and valuation of indigenous metal objects in the circum-Caribbean macroregion. Paper presented at the 26th Congress of the International Association for Caribbean Archaeology, 19-25 July, St. Maarten

Ambrose SH, Krigbaum J (2003) Bone chemistry and bioarchaeology. J Anthropol Archaeol 22:193-199

Balasse M (2002) Reconstructing dietary and environmental history from enamel isotopic analysis: time resolution of intra-tooth sequential sampling. Int J Osteoarchaeol 12:155-165

Balasse M, Ambrose SH, Smith A, Price TD (2002) The seasonal mobility model for prehistoric herders in the southwestern cape of South Africa assessed by isotopic analysis of sheep tooth enamel. J Archaeol Sci 29:917-932

Bataille CP, Laffoon J, Bowen GJ (2012) Mapping multiple source effects on the strontium isotopic signatures of ecosystems from the circumCaribbean region. Ecosphere 3:art118

Bender MM (1971) Variations in the ${ }^{13} \mathrm{C} /{ }^{12} \mathrm{C}$ ratios of plants in relation to the pathway of photosynthetic carbon dioxide. Phytochemistry 10: $1239-1244$

Bennett WC (1937) Excavations at La Mata, Maracay, Venezuela. Anthropological Papers of the American Museum of Natural History 36, part II, New York 
Bentley RA (2006) Strontium isotopes from the earth to the archaeological skeleton: a review. J Archaeol Method Theory 13:135-187

Bern CR, Townsend AR, Farmer GL (2005) Unexpected dominance of parent material strontium in a tropical forest on highly weathered soils. Ecology 86:626-632

Berry EW (1939) Geology and palaeontology of Lake Tacarigua, Venezuela. Proc Am Philos Soc 81:547-552

Blum JD, Taliaferro EH, Weisse MT, Holmes RT (2000) Changes in Sr/ $\mathrm{Ca}, \mathrm{Ba} / \mathrm{Ca}$ and ${ }^{87} \mathrm{Sr} /{ }^{86} \mathrm{Sr}$ ratios between trophic levels in two forest ecosystems in the northeastern U.S.A. Biogeochemistry 49:87-101

Booden MA, Panhuysen RGAM, Hoogland MLP, de Jong HN, Davies GR, Hofman CL (2008) Tracing human mobility with ${ }^{87} \mathrm{Sr} /{ }^{86} \mathrm{Sr}$ at Anse á la Gourde, Guadeloupe. In: Hofman CL, Hoogland MLP, van Gijn AL (eds) Crossing the Borders: new methods and techniques in the study of archaeological materials from the Caribbean. University of Alabama Press, Tuscaloosa, pp. 214-225

Boomert A (1987) Gifts of the Amazons: "green stone" pendants and beads as items of ceremonial exchange in Amazonia and the Caribbean. Antropológica 67:33-54

Boomert A (2000) Trinidad, Tobago and the Lower Orinoco interaction sphere: an archaeological/ethnohistorical study. PhD dissertation, Leiden University, Leiden

Bryant JD, Froelich PN (1995) A model of oxygen isotope fractionation in body water of large mammals. Geochim Cosmochim Acta 59: 4523-4537

Cody A (1993) Distribution of the exotic stone artifacts through the lesser antilles: implications for prehistoric interaction and exchange. In: Cummins A, King P (eds) Proceedings of the XIVth Congress of the International Association for Caribbean Archaeology. Barbados Museum and Historical Society, Bridgetown, pp. 204-226

Cook RA, Price TD (2015) Maize, mounds, and the movement of people: isotope analysis of a Mississippian/Fort Ancient case. J Archaeol Sci 61:112-128

Curet LA, Hauser, MW (eds) (2011) Islands at the crossroads: migration, seafaring, and interaction in the Caribbean. University of Alabama Press, Tuscaloosa

Dansgaard W (1964) Stable isotopes in precipitation. Tellus 16:436-468

DeFrance SD (2013) Zooarchaeology in the Caribbean: current research and future prospects. In: Keegan WF, Hofman CL, Rodríguez Ramos R (eds) The Oxford handbook of Caribbean archaeology. Oxford University Press, Oxford, pp. 378-390

DeNiro MJ, Epstein S (1978) Influence of diet on the distribution of carbon isotopes in animals. Geochim Cosmochim Acta 42:495-506

DeNiro MJ, Epstein S (1981) Influence of diet on the distribution of nitrogen isotopes in animals. Geochim Cosmochim Acta 45:341-351

Dupouy W (1946) La fauna de la Provincia de Venezuela según las relaciones geográficas del siglo XVI. Memoria de la Sociedad de Ciencias Naturales La Salle 6:45-55

Ehleringer JR, Casale JF, Lott MJ, Ford VL (2000) Tracing the geographical origin of cocaine. Nature 408:311-312

Ehleringer JR, Chesson LA, Valenzuela LO, Tipple BJ, Martinelli LA (2015) Stable isotopes trace the truth: from adulterated foods to crime scenes. Elements 11:259-264

Eisenberg JF (1989) Mammals of the Neotropics. The northern Neotropics, Vol. 1. University of Chicago Press, Chicago

Emmons L, Feer F (1997) Neotropical rainforest mammals: a field guide, 2nd edn. University of Chicago Press, Chicago

Ericson JE (1985) Strontium isotope characterization in the study of prehistoric human ecology. J Hum Evol 14:503-514

Faure G, Mensing T (2005) Isotopes: principles and applications, 3rd edn. Wiley, Hoboken

Fewkes JW (1907) The aborigines of Puerto Rico and neighboring islands. Bureau of American Ethnology Annual Report 25:1-220

Fittkau EJ (1969) The fauna of South America. In: Fittkau EJ, Illies J, Klinge H, Schwabe GH, Sioli H (eds) Biogeography and ecology in
South America, vol 2. Dr. W. Junk Publishers N.V, The Hague, pp. 624-650

Fitzpatrick SM, Ross AH (eds) (2010) Island shores, distant pasts: archaeological and biological approaches to the pre-Columbian settlement of the Caribbean. University Press of Florida, Gainesville

Font L, van der Peijl G, van Leuwen C, van Wetten I, Davies GR (2015) Identification of the geographical place of origin of an unidentified individual by multi-isotope analysis. Sci Justice 55:34-42

Gakuhari T, Intoh M, Nakano T, Yoneda M (2013) Strontium isotope analysis of prehistoric faunal remains excavated from Fais Island in Micronesia. People and culture in Oceania 29:69-81

García-Casco A, Knippenberg S, Rodríguez Ramos R, Harlow GE, Hofman CL, Pomo JC, Blanco-Quintero IF (2013) Pre-Columbian jadeitite artifacts from the Golden Rock Site, St. Eustatius, Lesser Antilles, with special reference to jadeitite artifacts from Elliot's, Antigua: implications for potential source regions and longdistance exchange networks in the Greater Caribbean. J Archaeol Sci 40:3153-3169

Giovas CM (2013) Foraging variability in the prehistoric Caribbean: multiple foraging optima, resource use, and anthropogenic impacts on Carriacou, Grenada. $\mathrm{PhD}$ dissertation, University of Washington, Seattle

Giovas CM, Fitzpatrick SM, Keegan WF (2015) Oh deer! Cervid bone artifacts in the Caribbean: a review and synthesis with new records. Paper presented at the XXVIth Conference of the International Association for Caribbean Archaeology, St. Martin

Giovas CM, LeFebvre MJ, Fitzpatrick SM (2012) New records for prehistoric introduction of Neotropical mammals to the West Indies: evidence from Carriacou, Lesser Antilles. J Biogeogr 39:476-487

Google Earth (2016a) 6.2.2.6613 Parque Nacional Los Roques. Worldview 2 - Digital Globe <http://www.google.com/earth/index. html $>$ [Viewed 11 February 2016]

Google Earth (2016b) 6.2.2.6613 Northern Venezuela. Landsat 8 satellite imagery <http://www.google.com/earth/index.html> [Viewed 18 January 2016]

Granberry J (2013) Indigenous languages of the Caribbean. In: Keegan WF, Hofman CL, Rodríguez Ramos R (eds) The Oxford handbook of Caribbean archaeology. Oxford University Press, Oxford, pp. 418-435

Grases P (1987) Alejandro de Humboldt por Tierras de Venezuela. Fundación de Promoción Cultural de Venezuela, Caracas

Graustein WC, Armstrong RL (1983) The use of strontium-87/strontium86 ratios to measure atmospheric transport into forested watersheds. Science 219:289-292

Grouard S (2001) Subsistance, systèmes techniques et gestion territoriale en milieu insulaireantillais précolombien-exploitation des vertébrés et des crustacés aux époques Saladoïdes et Troumassoïdes de Guadeloupe (400 av. J.-C. à 1500 ap. J.-C.). PhD dissertation, Université de Nanterre, Paris

Guiry EJ, Staniforth M, Nehlich O, Grimes V, Smith C, Harpley B, Noël S, Richards MP (2015) Tracing historical animal husbandry, meat trade, and food provisioning: a multi-isotopic approach to the analysis of shipwreck faunal remains from the William Salthouse, Port Phillip, Australia. Journal of Archaeological Science Reports 1:21-28

Harlow GE, Murphy AR, Hozjan DJ, de Mille CN, Levinson AA (2006) Pre- Columbian jadeite axes from Antigua, West Indies: description and possible sources. Can Mineral 44:305-321

Hartman G, Hovers E, Hublin JJ, Richards MP (2015) Isotopic evidence for Last Glacial climatic impacts on Neanderthal gazelle hunting territories at Amud Cave, Israel. J Hum Evol 84:71-82

Haviser JB (1994) South American faunal remains noted in archeological contexts on Curaçao and Bonaire: the potential for cultural implications. In: De horen en zijn echo: verzameling essays opgedragen aan Dr. Henry E. Coomans ter Gelegenheid van zijn Afscheid van de Universiteit van Amsterdam, Stichting Libri Antilliani/Zoölogisch Museum, Amsterdam, pp 124-127 
Hobson KA, Van Wilgenburg SL, Wassenaar LI, Powell RL, Still CJ, Craine JM (2012) A multi-isotope $\left(\delta^{13} \mathrm{C}, \delta^{15} \mathrm{~N}, \delta^{2} \mathrm{H}\right)$ feather isoscape to assign Afrotropical migrant birds to origins. Ecosphere 3(5):art44

Hodell DA, Quinn RL, Brenner M, Kamenov G (2004) Spatial variation of strontium isotopes $\left({ }^{87} \mathrm{Sr} /{ }^{86} \mathrm{Sr}\right)$ in the Maya region: a tool for tracking ancient human migration. J Archaeol Sci 31:585-601

Hofman CL, Hoogland MLP (2011) Unravelling the multi-scale networks of mobility and exchange in the pre-colonial circumCaribbean. In: Hofman CL, van Duijvenbode A (eds) Communities in contact. Essays in archaeology, ethnohistory \& ethnography of the Amerindian circum-Caribbean. Sidestone Press, Leiden, pp. 15-44

Hofman CL, Bright AJ, Boomert A, Knippenberg S (2007) Island rhythms: the web of social relationships and interaction networks in the Lesser Antillean archipelago between 400 B.C. and A.D. 1492. Lat Am Antiq 18:243-268

Hofman CL, Bright AJ, Hoogland MLP, Keegan WF (2008) Attractive ideas, desirable goods: examining the late Ceramic Age relationships between Greater and Lesser Antillean societies. Journal of Island and Coastal Archaeology 3:17-34

Hofman CL, Boomert A, Bright AJ, Hoogland MLP, Knippenberg S, Samson AVM (2011) Ties with the homelands: archipelagic interaction and the enduring role of the South and Central American mainlands in the pre-Columbian Lesser Antilles. In: Curet LA, Hauser MW (eds) Islands at the crossroads: migration, seafaring, and interaction in the Caribbean. University of Alabama Press, Tuscaloosa, pp. $73-86$

Hofman CL, Mol A, Hoogland MLP, Valcárcel Rojas R (2014a) Stage of encounters: migration, mobility and interaction in the pre-colonial and early colonial Caribbean. World Archaeol 46:590-609

Hofman CL, Mol A, Rodríguez Ramos R, Knippenberg S (2014b) Networks set in stone: archaic-ceramic interaction in the early precolonial northeastern Caribbean. In: Berard B, Losier C (eds) Archéologie Caraibe. Sidestone Press, Leiden, pp. 119-132

Jahn A (1927) Los aborígenes del occidente de Venezuela; Su historia, etnografía y afinidades lingüisticas. Caracas, Litografía y tipografía del Comercio

Katzenberg MA (2008) Stable isotope analysis: a tool for studying past diet, demography, and life history. In: Katzenberg MA, Saunders SR (eds) Biological anthropology of the human skeleton. John Wiley \& Sons Inc., New York, pp. 411-441

Keegan WF, Hofman CL, Rodríguez Ramos R (eds) (2013) The Oxford handbook of Caribbean archaeology. Oxford University Press, Oxford

Kennedy MJ, Chadwick OA, Vitousek PM, Derry LA, Hendricks DM (1998) Changing sources of base cations during ecosystem development, Hawaiian Islands. Geology 26:1015-1018

Kidder A (1948) The archaeology of Venezuela. In: Steward JH (ed) Handbook of South American Indians, Vol. 4. Bulletin No. 143. Bureau of American Ethnology, Smithsonian Institution, Washington DC, pp. 413-438

Kimura BK, LeFebvre MJ, Knodel HI, Turner MS, Fitzsimmons NS, Fitzpatrick SM, Mulligan CJ (2016) Origin of pre-Columbian guinea pigs from Caribbean archeological sites revealed through genetic analysis. Journal of Archaeological Science Reports 5:442-452

Knippenberg S (2007) Stone artefact production and exchange among the Lesser Antilles. ASLU Vol. 13. Leiden University Press, Leiden

Kohn MJ (1996) Predicting animal $\delta^{18} \mathrm{O}$ : accounting for diet and physiological adaptation. Geochim Cosmochim Acta 60:4811-4829

Lachniet MS, Patterson WP (2006) Use of correlation and stepwise regression to evaluate physical controls on the stable isotope values of Panamanian rain and surface waters. J Hydrol 324(1):115-140

Lachniet MS, Patterson WP (2009) Oxygen isotope values of precipitation and surface waters in northern central America (Belize and
Guatemala) are dominated by temperature and amount effects. Earth Planet Sci Lett 284:435-446

Laffoon JE (2012) Patterns of Paleomobility in the Ancient Antilles: an isotopic approach. $\mathrm{PhD}$ dissertation, Leiden University, Leiden

Laffoon JE (2013) Paleomobility research in Caribbean contexts: new perspectives from isotope analysis. In: Keegan WF, Hofman CL, Rodríguez Ramos R (eds) The Oxford handbook of Caribbean archaeology. Oxford University Press, Oxford, pp. 418-435

Laffoon JE, Davies GR, Hoogland MLP, Hofman CL (2012) Spatial variation of biologically available strontium isotopes $\left({ }^{87} \mathrm{Sr} /{ }^{86} \mathrm{Sr}\right)$ in an archipelagic setting: a case study from the Caribbean. J Archaeol Sci 39:2371-2384

Laffoon JE, Plomp E, Davies GR, Hoogland MLP, Hofman CL (2013a) The movement and exchange of dogs in the prehistoric Caribbean: an isotopic investigation. Int J Osteoarchaeol 25:454-465

Laffoon JE, Valcárcel Rojas R, Hofman CL (2013b) Oxygen and carbon isotope analysis of human dental enamel from the Caribbean: implications for investigating individual origins. Archaeometry 55:742-765

Laffoon JE, Rodríguez Ramos R, Chanlatte Baik L, Narganes Storde Y, Rodríguez Lopez M, Davies GR, Hofman CL (2014) Long-distance exchange in the precolonial circum-Caribbean: a multi-isotope study of animal tooth pendants from Puerto Rico. J Anthropol Archaeol 35:220-233

Lee-Thorp JA (2008) On isotopes and old bones*. Archaeometry 50: 925-950

LeFebvre MJ, deFrance SD (2014) Guinea pigs in the pre-Columbian West Indies. Journal of Island and Coastal Archaeology 9:16-44

Linares OJ (1998) Mamíferos de Venezuela. Caracas, Sociedad Conservacionista Audubon de Venezuela

Lovén S (1935) Origins of the Tainan culture, West Indies. Elanders Boktryckeri Aktiebolag, Goteborg

Luz B, Kolodny Y (1985) Oxygen isotope variations in phosphate of biogenic apatites, IV. Mammal teeth and bones. Earth Planet Sci Lett 75:29-36

Luz B, Kolodny Y, Horowitz M (1984) Fractionation of oxygen isotopes between mammalian bone-phosphate and environmental drinking water. Geochim Cosmochim Acta 48:1689-1693

Makarewicz CA, Sealy J (2015) Dietary reconstruction, mobility, and the analysis of ancient skeletal tissues: expanding the prospects of stable isotope research in archaeology. J Archaeol Sci 56:146-158

Marcano G (1971) [1889-1891]. Etnografia Precolombina de Venezuela. Instituto de Antropología e Historia, Universidad Central de Venezuela, Caracas (Translation from the original published in French between 1889 and 1991 in Paris)

Martín CA (1995) El Método del Análisis Lítico Para Establecer Modelos Tecnoeconómicos en Poblaciones Prehispánicas. Unpublished Trabajo de ascenso, Universidad Central de Venezuela, Caracas

Martin C, Bentaleb I, Kaandorp R, Iacumin P, Chatri K (2008) Intra-tooth study of modern rhinoceros enamel $\delta^{18} \mathrm{O}$ : is the difference between phosphate and carbonate $\delta^{18} \mathrm{O}$ a sound diagenetic test? Palaeogeogr Palaeoclimatol Palaeoecol 266:183-189

Mondolfi E (1986) Notes on the biology and status of the small wild cats in Venezuela. In: Miller SD, Everett DD (eds) Cats of the world: biology, Conservation and Management. National Wildlife Federation, Washington DC, pp. 125-146

Mol AAA, Hoogland MLP, Hofman CL (2015) Remotely local: egonetworks of late pre-colonial (AD 1000-1450) Saba, north-eastern Caribbean. J Archaeol Method Theory 22:275-205

Montgomery J (2010) Passports from the past: investigating human dispersals using strontium isotope analysis of tooth enamel. Ann Hum Biol 37:325-346

Morales PE (1984) Playa Chuao; Un Sitio Arqueológico Costero del Estado Aragua. Unpublished Tesis de grado, Escuela de Sociología y Antropología, Universidad Central de Venezuela, Caracas 
Newsom LA, Wing ES (2004) On land and sea: Native American uses of biological resources in the West Indies. University of Alabama Press, Tuscaloosa

Osgood C (1943) Excavations at Tocorón, Venezuela. Yale University Publications in Anthropology 29. Yale University Press, New Haven

Pagán-Jiménez JR (2013) Human-plant dynamics in the precolonial Antilles: a synthetic update. In: Keegan WF, Hofman CL, Rodríguez Ramos R (eds) The Oxford handbook of Caribbean archaeology. Oxford University Press, Oxford, pp. 391-406

Pavia JA, Marsaglia KM, Fitzpatrick SM (2013) Petrography and provenance of sand temper within ceramic sherds from Carriacou, Southern Grenadines, West Indies. Geoarchaeology 28:450-477

Pett-Ridge JC, Derry LA, Kurtz AC (2009) Sr isotopes as a tracer of weathering processes and dust inputs in a tropical granitoid watershed, Luquillo Mountains, Puerto Rico. Geochim Cosmochim Acta $73: 25-43$

Pietsch SJ, Hobson KA, Wassenaar LI, Tütken T (2011) Tracking cats: problems with placing feline carnivores on $\delta^{18} \mathrm{O}, \delta \mathrm{D}$ isoscapes. PLoS One 6(9):e24601

Pilaar Birch SE (2013) Stable isotopes in zooarchaeology: an introduction. Archaeological and Anthropological Science 5:81-83

Pilaar Birch SE, Miracle PT, Stevens RE, O'Connell TC (2016) Late Pleistocene/Early Holocene migratory behavior of ungulates using isotopic analysis of tooth enamel and its effects on forager mobility. PLoS One 11(6):e0155714

Podlesak DW, Torregrossa A-M, Ehleringer JR, Dearing MD, Passey $\mathrm{BH}$, Cerling TE (2008) Turnover of oxygen and hydrogen isotopes in the body water, $\mathrm{CO}_{2}$, hair, and enamel of a small mammal. Geochim Cosmochim Acta 72:19-35

Price TD, Johnson CM, Ezzo JA, Ericson J, Burton JH (1994) Residential mobility in the prehistoric Southwest United States: a preliminary study using strontium isotope analysis. J Archaeol Sci 21:315-330

Price TD, Burton JH, Bentley RA (2002) The characterization of biologically available strontium isotope ratios for the study of prehistoric migration. Archaeometry 44:117-135

Price TD, Burton JH, Sharer RJ, Buikstra JE, Wright LE, Traxler LP, Miller KA (2010) Kings and commoners at Copan: isotopic evidence for origins and movement in the Classic Maya period. J Anthropol Archaeol 29:15-32

Price TD, Meiggs D, Weber MJ, Pike-Tay A (2015) The migration of Late Pleistocene reindeer: isotopic evidence from northern Europe. Archaeol Anthropol Sci:1-24

Requena R (1932) Vestigios de la Atlántida. Tipografía Americana, Caracas

Rodríguez Ramos R (2010) Rethinking Puerto Rican precolonial history. University of Alabama Press, Tuscaloosa

Rodríguez Ramos R (2013) Isthmo-Antillean engagements. In: Keegan WF, Hofman CL, Rodríguez Ramos R (eds) The Oxford handbook of Caribbean archaeology. Oxford University Press, Oxford, pp. $155-170$

Rouse I (1986) Migrations in prehistory: inferring population movement from cultural remains. Yale University Press, New Haven

Rouse I (1992) The Taínos: rise and decline of the people who greeted Columbus. Yale University Press, New Haven

Rouse I (1964) Prehistory of the West Indies. Science 144(3618):499-513

Rozanski K, Araguás-Araguás L, Gonfiantini R (1993) Isotopic patterns in modern global precipitation. In Climate change in continental isotopic records. Geophysical Monograph Series 78:1-36

Santana J, Fregel R, Lightfoot E, Morales J, Alamón M, Guillén J, Moreno M, Rodríguez A (2016) The early colonial Atlantic world: new insights on the African diaspora from isotopic and ancient DNA analyses of a multiethnic 15th-seventeenth century burial population from the Canary Islands, Spain. Am J Phys Anthropol 159:300-312

Schapira D, Montano IA, Antczak A, Posada JM (2009) Using shell middens to assess effects of fishing on queen conch (Strombus gigas) populations in Los Roques Archipelago National Park, Venezuela. Marine biology 156(4):787-795

Schoeninger MJ, DeNiro MJ, Tauber H (1983) Stable nitrogen isotope ratios of bone collagen reflect marine and terrestrial components of prehistoric human diet. Science 220:1381-1383

Schoeninger MJ, DeNiro MJ (1984) Nitrogen and carbon isotopic composition of bone collagen from marine and terrestrial animals. Geochim Cosmochim Acta 48:625-639

Schroeder H, O'Connell TC, Evans JA, Shuler KA, Hedges RE (2009) Trans-Atlantic slavery: isotopic evidence for forced migration to Barbados. Am J Phys Anthropol 139:547-557

Sealy J, Armstrong R, Schrire C (1995) Beyond lifetime averages: tracing life histories through isotopic analysis of different calcified tissues from archaeological human skeletons. Antiquity 69:290-300

Sayre MP, Miller MJ, Rosenfeld SA (2015) Isotopic evidence for the trade and production of exotic marine mammal bone artifacts at Chavín de Huántar. Peru Archaeological and Anthropological Sciences:1-15

Siegel PE (1991) Migration research in Saladoid archaeology: a review. Florida Anthropologist 44:79-91

Siegel PE, Severin KP (1993) The first documented prehistoric goldcopper alloy artefact from the West Indies. J Archaeol Sci 20:67-79

Siegel PE (ed) (2005) Ancient Borinquen: archaeology and ethnohistory of native Puerto Rico. University of Alabama Press, Tuscaloosa

Sillen A, Hall G, Richardson S, Armstrong R (1998) ${ }^{87} \mathrm{Sr} /{ }^{86} \mathrm{Sr}$ ratios in modern and fossil food-webs of the Sterkfontein Valley: implications for early hominid habitat preference. Geochim Cosmochim Acta 62:2463-2473

Slovak NM, Paytan A (2011) Applications of Sr isotopes in archaeology. In: Baskaran M (ed) Handbook of environmental isotope geochemistry. Advances in isotope geology series 5. Springer, Berlin, pp. 743-768

Smith BN, Epstein S (1971) Two categories of ${ }^{13} \mathrm{C} /{ }^{12} \mathrm{C}$ ratios for higher plants. Plant Physiol 47(3):380-384

Sponheimer M, Lee-Thorp JA (1999) Oxygen isotopes in enamel carbonate and their ecological significance. J Archaeol Sci 26:723-728

Stahl PW (2009) Adventive vertebrates and historical ecology in the preColumbian Neotropics. Diversity 1:151-165

Sýkora A (2006) Manejo de Recursos Faunísticos Por los Pobladores del Sitio Prehispánico en Palmasola, Estado Carabobo, Venezuela. Unpublished Master's thesis. Facultad de Agronomía, Universidad Central de Venezuela, Maracay

Tello J (1979) Mamíferos de Venezuela. Fundación La Salle de Ciencias Naturales, Caracas

Terzer S, Wassenaar LI, Araguás-Araguás LJ, Aggarwal PK (2013) Global isoscapes for $\delta^{18} \mathrm{O}$ and $\delta^{2} \mathrm{H}$ in precipitation: improved prediction using regionalized climatic regression models. Hydrol Earth Syst Sci 17:4713-4728

Tewes ME, Schmidly DJ (1987) The neotropical felids: jaguar, ocelot, margay, and jaguarundi. Wild Furbearer Management and Conservation in North America. Ministry of Natural Resources, Ontario, pp. 697-711

Thornton EK (2011) Reconstructing ancient Maya animal trade through strontium isotope $\left({ }^{87} \mathrm{Sr} /{ }^{86} \mathrm{Sr}\right)$ analysis. J Archaeol Sci 38:3254-3263

Toth N, Woods M (1989) Molluscan shell knives and experimental cutmarks on bones. Journal of Field Archaeology 16:250-255

Valcárcel Rojas R, Martinón-Torres M (2013) Metals and indigenous societies in the Caribbean islands. In: Keegan WF, Hofman CL, Rodríguez Ramos R (eds) The Oxford handbook of Caribbean archaeology. Oxford University Press, Oxford, pp. 504-523

Van der Merwe NJ, Vogel JC (1978) ${ }^{13} \mathrm{C}$ content of human collagen as a measure of prehistoric diet in woodland North America. Nature 276: $815-816$

Veen T, Hjernquist MB, Van Wilgenburg SL, Hobson KA, Folmer E, Font L, Klaassen M (2014) Identifying the African wintering 
grounds of hybrid flycatchers using a multi-isotope $\left(\delta^{2} \mathrm{H}, \delta^{13} \mathrm{C}\right.$, $\delta^{15} \mathrm{~N}$ ) assignment approach. PLoS One 9(5):e98075

Vogel JC, van de Merwe NJ (1977) Isotopic evidence for early maize cultivation in New York state. Am Antiq 42:238-242

Von den Steinen K (1904) Ausgrabungen am Valenciasee. Globus 86: 101-108. Braunschweig

White TD (1992) Prehistoric cannibalism at Mancos 5MTUMR-2346. Princeton, Princeton University Press

White CD, Price TD, Longstaffe FJ (2007) Residential histories of the human sacrifices at the Moon Pyramid, Teotihuacan. Ancient Mesoamerica 18:159-172

Wing ES (2001) Native American use of animals in the Caribbean. In: Woods CA, Sergile FE (eds) Biogeography of the West Indies: patterns and perspectives, 2nd edn. CRC Press, Boca Raton, pp. $481-518$

Wing ES (2008) Native pets and camp followers in the West Indies. In: Reitz E, Scarry CM, Scudder SJ (eds) Case studies in environmental archaeology. Springer, New York, pp. 405-425

Wing ES (2012) Zooarchaeology of west Indian land mammals. In: Borroto-Páez R, Woods CA, Sergile FE (eds) Terrestrial mammals of the West Indies. Florida Museum of Natural History and Wachoota Press, Gainesville, pp. 341-356

Wright LE, Valdés JA, Burton JH, Price TD, Schwarcz HP (2010) The children of Kaminaljuyu: isotopic insight into diet and long distance interaction in Mesoamerica. J Anthropol Archaeol 29:155-178 